\title{
The Taxation of Crowdfunding: Income Tax Uncertainties and a Safe Harbor Test to Claim Gift Tax Exclusion
}

\author{
Paul Battista*
}

INTRODUCTION

Crowdfunding is defined as the process of asking a large number of separate third parties for relatively small amounts of money to fund an endeavor. ${ }^{1}$ Although the concept of asking for financial "contributions" is not new, seeking funds from others via websites on the Internet is relatively new. ${ }^{2}$ It has been reported that the term crowdfunding was not used until 2006, and two of the most popular crowdfunding sites, Kickstarter and Indiegogo, were not founded until 2009 and 2008, respectively. ${ }^{3}$ Information is not available regarding the annual number of crowdfunding endeavors, the number of funding participants, or the total amount of money obtained in successful crowdfunding campaigns, but accurate information is available that shows crowdfunding is encompassing an impressive number of participants and amounts of money. ${ }^{4}$ Professor C. Steven Bradford stated in 2012 that "in the aggregate, crowdfunding is huge," and since his statement in 2012, crowdfunding has grown dramatically. For example, Kickstarter reports that between 2009 and August 2015 over 9 million backers pledged approximately $\$ 1.9$ billion to more than 90,000 projects, representing over 24 million total pledges. ${ }^{6}$ More than $\$ 500$ million of the pledged amounts were reported to have occurred between March 2013 and March

\footnotetext{
* J.D., Seton Hall University School of Law; L.L.M. (Taxation), Georgetown University Law Center. Paul Battista is an entertainment and tax attorney in Los Angeles.

1. Daren C. Brabham, Crowdsourcing 37 (2013); C. Steven Bradford, Crowdfunding and the Federal Securities Laws, 2012 Colum. Bus. L. Rev. 1, 10 (2012); see Edan Burkett, A Crowdfunding Exemption? Online Investment Crowdfunding and U.S. Security Regulation, 13 TRANSACTIONS: TENN. J. BuS. L. 63, 66 (2011) (noting that definitions of crowdfunding vary and describing a definition).

2. Bradford, supra note 1, at 11.

3. Burkett, supra note 1, at 70, 71 n.51.

4. See Bradford, supra note 1, at 11.

5. Id.

6. Stats, KiCKSTARTER, https://www.kickstarter.com/help/stats (last visited Aug. 19, 2015).
} 
2014. ${ }^{7}$ Indiegogo also reported that it had a $1000 \%$ increase in amounts obtained between 2012 and 2014 with over 200,000 campaigns launched through its site. ${ }^{8}$

As with any distinctly new financing vehicle, there are many legal issues raised by crowdfunding that have not been explored or answered. One such issue is the income tax consequences associated with crowdfunding. ${ }^{9}$ Although the academy has not yet widely addressed the issues ${ }^{10}$ and the Internal Revenue Service (IRS) has yet to provide any formal guidance, ${ }^{11}$ it has been pointed out in the popular press that there is a lack of clarity that needs to be addressed. ${ }^{12}$ As one journalist succinctly states: "Taxing crowdfunding pledges is one of a host of policy considerations that government agencies must address in coming months as the technique becomes increasing[ly] popular and potentially hides questionable business dealings by both companies and investors." 13 It has also been noted that the most popular crowdfunding sites are

7. $O M G$, KICKSTARTER, https://www.kickstarter.com/1billion (last visited Aug. 19, 2015).

8. Katherine Noyes, Why Investors Are Pouring Millions Into Crowdfunding, FORTUNE (Apr. 17, 2014, 6:47 PM), http://fortune.com/2014/04/17/why-investors-are-pouring-millions-intocrowdfunding/.

9. This Article addresses only the income-tax issues associated with crowdfunding.

10. E.g., Eric Dietz, The Tax Code's Crowdfunding Dilemma: The Temptation of Kickstarter Creators to Use the Gift Exclusion Under Section 102(a), 37 HAMLINE L. REV. 293, 309 (2014) (arguing that Kickstarter should be responsible for advising crowdfunders that they should not exclude crowdfunding receipts from taxable income as a gift under Code section 102).

11. The Canada Revenue Agency (CRA) issued technical interpretations regarding the taxation of crowdfunding. Treatment of Funds Obtained Through "Crowdfunding" Received by a Taxpayer, Can. Revenue Agency Doc. No. 2013-0484941E5 (Aug. 16, 2013), http://www.canadiantaxlitigation.com/wp-content/uploads/2013/11/2013-0484941E5.txt; What Is the Tax Treatment of Amounts Received Through Crowdfunding?, Can. Revenue Agency Doc. No. 2013-0508971E5 (Oct. 25, 2013), http://www.canadiantaxlitigation.com/wpcontent/uploads/2013/11/2013-0508971E5.txt ("[T]he CRA would not be able to make any determination on the income tax consequences of a particular crowdfunding arrangement without a full review of all the facts, circumstances and documentation, if any, relating to [the crowdfunding] arrangement."), What Is the Tax Treatment of Amounts Received Through Crowdfunding?, Can. Revenue Agency Doc. No. 2013-0509101E5 (Oct. 29, 2013), http://www.canadiantaxlitigation.com/wp-content/uploads/2013/11/2013-0509101E5.txt

("[V]oluntary payments (or other transfers of benefits) received by virtue of a profession or by virtue of carrying on a business are considered to be taxable receipts.").

12. Nat Rudarakanchana, Crowdfunding: Income or Gift? IRS Taxes and SEC Regulations Could Hurt Startups and Innovation on Kickstarter and Indiegogo, INT'L BuS. TIMES (July 19, 2013, 9:14 PM), http://www.ibtimes.com/crowdfunding-income-or-gift-irs-taxes-sec-regulationscould-hurt-startups-innovation-kickstarter ("Say you're raising money on Kickstarter for an independent film project: Are the proceeds a sort of communal gift-giving or simply a clever source of standard taxable income? The distinction matters, but nobody seems to know for sure. The U.S. Internal Revenue Service may have an opinion on the matter, but if the agency does, it's not saying, leaving developers on crowdsourcing platforms such as Kickstarter and Indiegogo in the dark. One consequence of the lack of clarity: A likely tax court challenge ....").

13. Id. 
attracting individuals from the creative fields of film, music, television and other arts-fields traditionally not populated by individuals accustomed to addressing business and tax issues. ${ }^{14}$

Part I of this Article will provide an overview of the most popular types of crowdfunding models and an example of an actual crowdfunding campaign in order to highlight the tax issues. Part II addresses the tax aspects of crowdfunding models that provide loans (model 4) and equity investments (model 5). Part III will present the tax consequences when a tax-exempt entity is used to crowdfund using model 1 (donations) and models 2 and 3 (reward and pre-purchase). Part IV and Part $\mathrm{V}$ will provide a review of current income tax and gift tax laws as they are applied to crowdfunding model 1 (donations) and models 2 and 3 (reward and pre-purchase) and will show that the current tax laws do not provide a bright-line answer to whether or not a crowdfunding transaction in the latter models is excludable from income. However, there are guidelines that emerge from current tax law that require administrative action by the IRS to clarify income and gift tax uncertainties regarding crowdfunding. In Part VI it is recommended that the IRS should issue guidance stating that funds received in a crowdfunding campaign are gross income under Internal Revenue Code section $61 .{ }^{15}$ It is also recommended that the IRS should provide a safeharbor test, as described in Part VI, so as to determine if funds received in crowdfunding model 1 (donations) and models 2 and 3 (reward and pre-purchase) are gifts that are not subject to federal income tax, which would make the taxation of crowdfunding more efficient, equitable, and easier to administer. ${ }^{16}$

14. See Suw Charman-Anderson, Kickstarter's Sting in the Tail: Tax, Forbes (May 23, 2012, 12:41 PM), http://www.forbes.com/sites/suwcharmananderson/2012/05/23/kickstarters-sting-in-thetail-tax/ ("One particularly important issue, which has gone largely undiscussed in the crowdfunding community, is tax. In my long-past life as an underemployed music journalist, I met a lot of musicians who were focused exclusively on the creative aspects of their lives. They didn't want to understand how record labels structured their contracts or what the legalese meant. They didn't want to think about what the words or the numbers really meant; if they could have ignored it completely, they would have. Now, some 15 years later, Kickstarter is a honey pot for creative people, attracting them with the lure of all that sweet golden money that will allow them to make the art they've always wanted to. And attitudes to the business side of things will, I suspect, not have changed."). Another example of when lack of clarity can affect compliance is seen in the taxation of automobile expenses. See James Alm \& Jay A. Soled, The Internal Revenue Code and Automobiles: A Case Study of Taxpayer Noncompliance, 14 FLA. TAX REV. 419, 442 (2013) ("Aside from . . . deliberate violations, the lack of clear rules is another contributory factor in taxpayer noncompliance.").

15. All references to the Internal Revenue Code are hereinafter the "Code."

16. See infra Part VI. 


\section{CROWDFUNDING MODELS}

Five crowdfunding models may be identified and classified on the basis of the type of return provided in exchange for the funds provided. ${ }^{17}$ The five models are: "(1) the donation model; (2) the reward model; (3) the pre-purchase model; (4) the lending model; and (5) the equity model." " A contributor in the donation model does not receive anything tangible in return for the contribution. ${ }^{19}$ In the reward model, the contributor usually receives something of marketable value in return; whereas in the pre-purchase model, the contributor is promised a copy of the item that the organizer of the crowdfunding campaign plans to create: for example, if the campaign is successful, the contributor may receive a copy of a film created. ${ }^{20}$ The lending model employed by sites such as Kiva involves loans, usually interest free and in very small amounts. ${ }^{21}$ Before the passage of the Jumpstart Our Business Startups (JOBS) Act in 2012, securities laws had prohibited the equity model in the United States. ${ }^{22}$ Compliance with the new laws allows contributors an equity ownership in an endeavor in exchange for the contributions, which are properly called investments. ${ }^{23}$

\section{A. Crowdfunding Example}

A recently successful reward-type of crowdfunding campaign undertaken in order to produce a documentary film will serve as a good example, illustrating the potential income tax issues that arise when

\footnotetext{
17. Bradford, supra note 1, at 14.

18. Id. at $14-15$.

19. Id. at 15 .

20. Id. at 16 .

21. See id. at 20-21, 29; see also Sarah B. Lawsky, Money for Nothing: Charitable Deductions for Microfinance Lenders, 61 SMU L. REV. 1525, 1534 (2008).

22. See Burkett, supra note 1, at 75 ("Securities laws, however, are a formidable barrier to investment crowdfunding in the United States ....”). The Jumpstart Our Business Startups Act (JOBS Act) includes an exemption from registration for crowdfunded offers and sales of securities. 15 U.S.C. §§ 77a-77aa (2012); 15 U.S.C. § 78a (2012); Pub. L. No. 112-106, §§ 301-05, 126 Stat. 306, 315-23 (2012). This crowdfunding model is not yet law so these models may not provide ownership or rewards in exchange for equity investments. John S. (Jack) Wroldsen, The Social Network and the Crowdfund Act: Zuckerberg, Saverin, and Venture Capitalists' Dilution of the Crowd, 15 VAND. J. ENT. \& TECH. L. 583, 585 (2013). The Securities and Exchange Commission is scheduled to release final rules to implement the new law by October 2015. Office of Mgmt. and Budget, View Rule, http://www.reginfo.gov/public/do/eAgendaViewRule?pubId=201410\&RIN=3235-AL37 (last visited Aug. 19, 2015).

23. See Joan MacLeod Heminway, What is a Security in the Crowdfunding Era?, 7 OHIO ST. ENTREPRENEURIAL BUS. L.J. 335, 357, 359 (2012) (explaining crowdfunding's investment model).
} 
goods and services (perks or rewards) are provided in exchange for money. The filmmakers of a documentary film entitled Be Natural: The Untold Story of Alice Guy-Blaché (hereinafter referred to as the GuyBlaché film) obtained approximately $\$ 200,000$ from crowdfunding to complete the project. $^{24}$ The following table is a selective sample of the "rewards" promised for each level of money provided to the project; it also shows the number of contributors and the total amount provided at each monetary level. The information provided in the table is for illustrative purposes only and represents only fourteen of the forty-six monetary levels established for the campaign, ${ }^{25}$ only a portion of the total amount collected, and only a portion of the total number of contributors. $^{26}$ The total number of individuals who contributed to the project was $3,840 .{ }^{27} \quad 2,992$ backers provided $\$ 100$ or less and represented $\$ 99,348$ of the total contributed; whereas 135 backers contributed $\$ 150$ or more and represented $\$ 74,860$ of the total amount contributed. $^{28}$

\begin{tabular}{|l|l|l|l|}
\hline Amount & $\begin{array}{l}\text { Number of } \\
\text { Contributors }\end{array}$ & $\begin{array}{l}\text { Total } \\
\text { Amount } \\
\text { Contributed }\end{array}$ & "Reward" \\
\hline$\$ 1$ & 303 & $\$ 303$ & A general "thank you" \\
\hline$\$ 10$ & 343 & $\$ 3,430$ & $\begin{array}{l}\text { A "thank you" sent by } \\
\text { email or twitter from } \\
\text { the producers }\end{array}$ \\
\hline$\$ 15$ & 242 & $\$ 3,630$ & $\begin{array}{l}\text { A "thank you" mailed } \\
\text { by postcard }\end{array}$ \\
\hline
\end{tabular}

24. Pamela Green \& Jarik van Sluijs, Be Natural: The Untold Story of Alice Guy-Blaché, KICKSTARTER, https://www.kickstarter.com/projects/benatural/be-natural-the-untold-story-of-aliceguy-blache/description (last visited Aug. 19, 2015). Alice Guy-Blaché (1873-1968):

wrote, directed, or produced more than 1,000 films. At age 23, she was one of the first filmmakers to make a narrative movie. She pioneered the technology of syncing sound to film. She created the first film with an all African-American cast. And she was the first woman to build and run a film studio. Any idea who she is? If not, you're far from alone. A majority of people - even Hollywood directors, actors, and producers - have never heard of her.

Adrienne Vogt, The First Woman Behind a Camera, Now Forgotten, The Daily Beast (Aug. 21, 2013, 4:45 AM), http://www.thedailybeast.com/witw/articles/2013/08/20/alice-guy-blachhollywood-s-female-pioneer.html.

25. Green \& van Sluijs, supra note 24. Each monetary level includes all of the rewards offered on all levels above the amount contributed. Id.

26. See id.

27. Id.

28. Id. 


\begin{tabular}{|c|c|c|c|}
\hline$\$ 19$ & 173 & $\$ 3,287$ & $\begin{array}{l}\text { Receive a digital } \\
\text { download of all the } \\
\text { project Kickstarter } \\
\text { videos - the pitch, the } \\
\text { trailer, the updates, plus } \\
\text { a special behind the } \\
\text { scenes video }\end{array}$ \\
\hline$\$ 25$ & 150 & $\$ 3,750$ & $\begin{array}{l}\text { A“thank you" tweet or } \\
\text { email, and a "Be } \\
\text { Natural" project } \\
\text { bumper sticker }\end{array}$ \\
\hline$\$ 29$ & 93 & $\$ 2,697$ & $\begin{array}{l}\text { A copy of one of Alice } \\
\text { Guy-Blaché's scripts } \\
\text { and marketing } \\
\text { materials promoting the } \\
\text { release of the film }\end{array}$ \\
\hline$\$ 35$ & 605 & $\$ 21,175$ & $\begin{array}{l}\text { Digital download of the } \\
\text { film }\end{array}$ \\
\hline$\$ 99$ & 10 & $\$ 990$ & $\begin{array}{l}\text { A DVD copy of Alice } \\
\text { Guy-Blaché's film "A } \\
\text { Fool and His Money" } \\
(1912)\end{array}$ \\
\hline$\$ 250$ & 18 & $\$ 4,500$ & $\begin{array}{l}\text { DVD of the final film, } \\
\text { a "Be Natural" project } \\
\text { pin, baseball hat, water } \\
\text { bottle, pen, notebook, } \\
\text { and t-shirt, plus a } \\
\text { "thank you" by email } \\
\text { or tweet }\end{array}$ \\
\hline$\$ 500$ & 15 & $\$ 7,500$ & $\begin{array}{l}\text { Contributor's name on } \\
\text { the thank-you list on } \\
\text { the project's website, } \\
\text { DVD of the final film, } \\
\text { a "Be Natural" project } \\
\text { postcard, bumper } \\
\text { sticker, pin, tote bag, } \\
\text { pen, baseball cap, } \\
\text { coffee/tea mug, water } \\
\text { bottle, notebook, and t- } \\
\text { shirt }\end{array}$ \\
\hline$\$ 1,000$ & 7 & $\$ 7,000$ & DVD of the final film, \\
\hline
\end{tabular}




\begin{tabular}{|c|c|c|c|}
\hline & & & $\begin{array}{l}\text { a "Be Natural" project } \\
\text { postcard, bumper } \\
\text { sticker, pin, dog or cat } \\
\text { collar, tote bag, pen, } \\
\text { baseball cap, iPhone } \\
\text { case, coffee/tea mug, } \\
\text { water bottle, notebook, } \\
\text { beret, charm bracelet, } \\
\text { scarf, tie, bow tie, and } \\
\text { t-shirt }\end{array}$ \\
\hline$\$ 1,500$ & 4 & $\$ 6,000$ & $\begin{array}{l}\text { Two tickets to the } \\
\text { family and friends } \\
\text { screening in LA or } \\
\text { NYC and to the after } \\
\text { party (travel and } \\
\text { accommodations not } \\
\text { included). } \\
\text { Contributor's name on } \\
\text { the thank-you list on } \\
\text { the project's website, } \\
\text { DVD of the final film, } \\
\text { and any three of the } \\
\text { following: a "Be } \\
\text { Natural" project } \\
\text { postcard, bumper } \\
\text { sticker, pin, dog or cat } \\
\text { collar, tote bag, pen, } \\
\text { baseball cap, iPhone } \\
\text { case, coffee/tea mug, } \\
\text { water bottle, notebook, } \\
\text { beret, charm bracelet, } \\
\text { scarf, tie, bow tie, and } \\
\text { t-shirt }\end{array}$ \\
\hline$\$ 2,500$ & 9 & $\$ 22,500$ & $\begin{array}{l}\text { Two tickets to a test } \\
\text { screening in LA or } \\
\text { NYC followed by a } \\
\text { filmmakers Q\&A, } \\
\text { where you'll get to give } \\
\text { all your feedback } \\
\text { (travel and } \\
\text { accommodations not } \\
\text { included). "Thank }\end{array}$ \\
\hline
\end{tabular}




\begin{tabular}{|c|c|c|c|}
\hline & & & $\begin{array}{l}\text { you" in the credits of } \\
\text { the film. DVD of the } \\
\text { final film, and any five } \\
\text { of the following: a "Be } \\
\text { Natural" project } \\
\text { postcard, bumper } \\
\text { sticker, pin, dog or cat } \\
\text { collar, tote bag, pen, } \\
\text { baseball cap, iPhone } \\
\text { case, coffee/tea mug, } \\
\text { water bottle, notebook, } \\
\text { beret, charm bracelet, } \\
\text { scarf, tie, bow tie, and } \\
\text { t-shirt }\end{array}$ \\
\hline$\$ 5,000$ & 1 & $\$ 5,000$ & $\begin{array}{l}\text { Spend the day with the } \\
\text { filmmakers in LA } \\
\text { (travel and } \\
\text { accommodations not } \\
\text { included) to review the } \\
\text { research and behind the } \\
\text { scenes action in telling } \\
\text { Alice's amazing story. } \\
\text { DVD of the final film, } \\
\text { and any five of the } \\
\text { following: a "Be } \\
\text { Natural" project } \\
\text { postcard, bumper } \\
\text { sticker, pin, dog or cat } \\
\text { collar, tote bag, pen, } \\
\text { baseball cap, iPhone } \\
\text { case, coffee/tea mug, } \\
\text { water bottle, notebook, } \\
\text { beret, charm bracelet, } \\
\text { scarf, tie, bow tie, and } \\
\text { t-shirt }\end{array}$ \\
\hline
\end{tabular}

It is common for crowdfunding campaigns to attract a relatively large number of contributors who provide relatively small contribution

29. Id. (some descriptions in the "Reward" column are direct quotes, others are modified for grammar, style, and punctuation). 
amounts. $^{30}$ However, the smaller number of contributors who provide larger contributions often provide total contributions that exceed the total contributions provided by a large number of small amount contributors. ${ }^{31}$ The following sections will discuss the income tax consequences of the five crowdfunding models using facts from the crowdfunding endeavor above, as applicable.

\section{TAX CONSEQUENCES OF CROWDFUNDING MODELS 4 AND 5 (LOANS \& EQUITY)}

\section{A. Lending Model}

The current Code addresses the income tax consequences when crowdfunding is based on bona fide loans that provide for the payment of interest and is well settled. Money received by virtue of a bona fide loan is not income to the recipient, ${ }^{32}$ while it is also clear that interest paid by a borrower is income to the lender. ${ }^{33}$ The Code addresses many issues in situations where loans are the basis of raising money through crowdfunding. Some of these issues include: income from the discharge of indebtedness, ${ }^{34}$ exclusions from income when indebtedness is discharged ${ }^{35}$ the tax consequences of loans with below-market interest rates, ${ }^{36}$ and the exclusion of cancelled debt from income when the facts support a conclusion that it was a gift. ${ }^{37}$

\section{B. Equity Model}

Code section 351(a) states that: "No gain or loss shall be recognized if property is transferred to a corporation by one or more persons solely in exchange for stock in such corporation and immediately after the exchange such person or persons are in control (as defined in section 368(c)) of the corporation." ${ }^{, 38}$ Therefore, assuming all of the

30. Ethan Mollick, The Dynamics of Crowdfunding: An Exploratory Study, 29 J. Bus. VENTURING 1, 1 (2014).

31. Id.

32. Boris I. BitTKER ET AL., FEDERAL InCOME TAXATION OF INDIVIDUALS $3-4$ (3d ed. 2013).

33. Treas. Reg. § 1.61-7(a) (2015) ("As a general rule, interest received by or credited to the taxpayer constitutes gross income and is fully taxable.").

34. I.R.C. § 61(a)(12) (2012).

35. Id. $\S \S 108,1017$ (2012 \& Supp. 2014).

36. Id. $\$ 7872(2012)$.

37. Id. $\S 102(2012)$.

38. Id. § 351(a) (2012). 
requirements are met, there is no gain or loss recognized when participants provide money to a crowdfunding campaign for which they receive ownership in a corporation, since money qualifies as property. ${ }^{39}$ If the investor receives "rewards" or "perks" from the corporation in addition to an equity position, the Code clearly states that the investor shall recognize gain (but not loss) to the extent of the fair market value of the property received. ${ }^{40}$ For example, those investors who provided $\$ 35$ and received a digital copy of the completed film in addition to an equity position would be required to recognize gain to the extent of the fair market value of the digital download of the film. ${ }^{41}$ Assuming the control requirement of section 351(a) is met, these taxpayers received a \$35 value of stock in addition to the fair market value of the digital download of the film (assumed to be valued at $\$ 20$ ) for a total of $\$ 55$ received. The $\$ 55$ received, less the basis of the property provided to the corporation (\$35 cash), leaves $\$ 20$ of realized taxable income. ${ }^{42}$ These taxpayers also hold stock ownership in the amount of $\$ 35$ at the end of the transaction. ${ }^{43}$

If the investment is in a partnership vehicle and no perks or rewards are provided, it is also clear that no gain or loss will be recognized by the partners (that is, crowdfunding investors) in exchange for the ownership interest. $^{44}$ For example, if an individual gives a partnership $\$ 100$ for a partnership interest and receives no property back, then no gain or loss will be recognized and the partner's basis in the partnership would be $\$ 100$. $^{45}$ The tax treatment of rewards or perks received from the partnership is clear in the Code, but the ultimate tax treatment depends

39. See id.; see also E. I. Du Pont de Nemours \& Co. v. United States, 471 F.2d 1211, 1214 (Ct. Cl. 1973) (including money in definition of property). See supra note 22 and accompanying text.

40. I.R.C. $§ 351$ (b). For clarity and brevity, the above example does not address the results if the taxpayers provide property wherein the recognized gain would be the lesser of the value of the boot received or the gain created by the difference between the basis and the fair market value of the property provided by the taxpayer.

41. See Green \& van Sluijs, supra note 24 .

42. This occurs because the gain recognized under Code section 351 will not exceed the gain that would be recognized if section 351 did not apply to the transaction. See I.R.C. § 351(b); Treas. Reg. § 1.351-2 (2015).

43. Code section 358(a) provides rules for determining the basis of the taxpayers' stock and boot received. The basis of the stock received by the taxpayers in the above example is the value of the property provided by the taxpayer $(\$ 35)$, decreased by the fair market value of other property received by the taxpayer $(\$ 20)$, and increased by the amount of gain recognized by the taxpayer in the exchange $(\$ 20)$. The basis of the stock received by the taxpayers in the above example is therefore $\$ 35$.

44. I.R.C. § 721(a) (2012).

45. Id. 
on the facts and circumstances of each transaction. ${ }^{46}$ The inquiry starts with the understanding that, in general, distributions of property from a partnership to a partner do not result in gain to the partner if the partner's basis in the partnership exceeds the value of the distribution from the partnership and the distributions are out of operating cash flow, guaranteed payments, or preferred returns. ${ }^{47}$ If the above example is changed so that the partner receives property back that has a fair market value of $\$ 10$, then, if the form of the transaction is respected, the partner would not recognize gain on the distribution. ${ }^{48}$ However, this nonrecognition treatment may not be applicable in situations where a partner receives property back from the partnership and it is determined that the transaction is a sale, which would alter the tax consequences. ${ }^{49}$ The regulations issued by the Treasury Department provide guidance in determining the tax consequences in both crowdfunding and noncrowdfunding transactions that involve the transfer of money in exchange for a partnership interest with the additional distribution of property to the partner. ${ }^{50}$ If the above example were a crowdfunding campaign, then an exchange where a partner gives the partnership $\$ 100$ for a partnership interest and receives a DVD of the film to be produced in the crowdfunding campaign (that is, receives "property") may be characterized as a sale or exchange "if, in fact, the distribution was made in order to effect an exchange of property between two or more of the

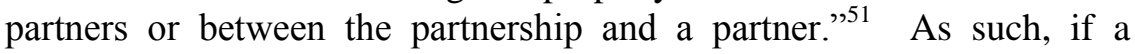
transfer of money or property by a partnership to a partner occurs with a transfer of money or property from a partner to a partnership and

46. See, e.g., id. § 707(a) (2012) (controlling partners not acting in capacity as partner); Treas. Reg. $\S \S 1.707-1,-3,-6$ (2015) (regulating partners not acting in partner capacity, disguised sales of property to partnerships, and disguised sales by partnership to partner, respectively).

47. I.R.C. $\$ \S 721-22,731-32$ (2012).

48. There is no recognition of gain or loss unless Code sections 704(c)(1)(B), 737, or 751(b) apply. The recipient of the property takes a transferred basis and the partner's outside basis is reduced by the transferred basis in the property distributed. Id. §§ 731(a), 732(a), 733.

49. Treasury Regulation section 1.721-1(a) provides that

[s]ection $721 \ldots$ shall not apply to a transaction between a partnership and a partner not acting in his capacity as a partner since such a transaction is governed by section $707 \ldots$ In all cases, the substance of the transaction will govern, rather than its form.... Thus, if the transfer of property by the partner to the partnership results in the receipt by the partner of money or other consideration, ... the transaction will be treated as a sale or exchange under section $707 \ldots$ rather than as a contribution under section 721.

50. Treas. Reg. $\S \S 1.707-1$ through -9 .

51. Id. $\S 1.731-1(\mathrm{c})(3)(\mathrm{ii})$ (2015). Rules similar to those in section 1.707-3 "apply in determining whether a transfer of property by a partnership to a partner and one or more transfers of money or other consideration by that partner to the partnership are treated as a sale of property, in whole or in part, to the partner." Id. § 1.707-6(a); see also id. § 1.721-1. 
together these transactions are determined to be a sale or exchange, then nonrecognition of Code sections 721 and 731 is not applicable and the partner must recognize income from the transaction. ${ }^{52}$ In general, the first step is to review each transaction so as to determine whether a sale has occurred. ${ }^{53}$ To be considered a sale the following two requirements must be satisfied: first, the money or other consideration would not have been transferred if the property was not also transferred; and second, in the event that the transfers are not made simultaneously, then the subsequent transfer does not depend on the risks of operating the partnership. $^{54}$ There is a rebuttable presumption that transactions occurring within two years of each other are a sale. ${ }^{55}$

The Regulations provide a nonexclusive list of ten factors that tend to prove the existence of a sale under Code section 707. ${ }^{56}$ As applied to crowdfunding, of the ten factors the following four would support the conclusion that providing perks or rewards in addition to a partnership interest is a sale as provided in the Regulations: (1) the timing and amount of the transfer of the perks or rewards can be determined with reasonable certainty at the time the money is provided to the partnership by the investor; ${ }^{57}(2)$ when the partnership spends an investor's money then that investor has a legally enforceable right to the promised perks or rewards ${ }^{58}$ (3) other investors must provide money contributions as a prerequisite to the partnership's ability to provide the perks or rewards, ${ }^{59}$ and (4) a partner is not required to return a perk or reward once it is provided by the partnership. ${ }^{60}$ It should be recognized that Code section 707 was enacted to curb abuses by partnerships in which there is an attempt to "avoid the recognition of gain on the contributed property by the contributor." ${ }^{\prime}$ While it could be argued that providing perks and

52. I.R.C. § 707.

53. Id.; see also Treas. Reg. § 1.707-3 (discussing treatment of sales).

54. Treas. Reg. $\S 1.707-3(b)(1)(i)-(i i)$. There are exceptions to this rule contained in Treasury Regulation section 1.707-4, for example, guaranteed payments for capital and reasonable preferred returns. Id. § 1.707-4.

55. Id. $\S 1.707-3(\mathrm{c})(1)$. Transfers made more than two years apart are presumed not to be a sale. Id. $\S 1.707-3(\mathrm{~d})$

56. $I d . \S 1.707-3(\mathrm{~b})(2)(\mathrm{i})-(\mathrm{x})$

57. Id. $\S 1.707-3(\mathrm{~b})(2)(\mathrm{i})$.

58. Id. $\S 1.707-3(\mathrm{~b})(2)(\mathrm{ii})$. See generally Paul Battista, IndePENDENT Film Producing: How to Produce a LOW-Budget InDEPENDENT FiLm (2013) (explaining the legal obligations when providing crowdfunding perks or rewards).

59. Treas. Reg. § 1.707-3(b)(2)(iv).

60. Id. $\S 1.707-3(\mathrm{~b})(2)(\mathrm{x})$.

61. Laura E. Cunningham \& Noel B. Cunningham, The Logic of Subchapter K 228 (4th ed. 2011). 
rewards when a partner provides cash are not the types of transactions Code section 707 was enacted to address, nevertheless, reviewing the facts of providing perks and rewards as applied to the list of the above factors will most likely lead to the conclusion that the provision of perks and rewards are sales under Code section 707 and would require the recognition of gain to the extent of the fair market value of the perks and rewards received. Using the example above, those partnership investors who provided $\$ 35$ and received a digital copy of the completed film would be required to recognize gain to the extent of the fair market value of the digital download of the film. These taxpayers received a $\$ 35$ value of ownership in the partnership in addition to the fair market value of the digital download of the film (assumed to be valued at \$20) for a total of $\$ 55$ received, less the basis of the property provided to the partnership (\$35 cash), which equals a current amount of realized taxable income of $\$ 20 .^{62}$

\section{TAX CONSEQUENCES OF CROWDFUNDING MODEL 1 (DONATIONS) AND MODELS 2 AND 3 (REWARD \& PRE-PURCHASE) WHEN USING A TAX-EXEMPT ENTITY}

A crowdfunding campaign seeking to utilize the benefits of taxexempt status can either create a tax-exempt entity through which a project will be completed or utilize a fiscal sponsorship model wherein the crowdfunding party contracts with an existing tax-exempt entity in order to utilize the latter's existing tax-exempt status. ${ }^{63}$ The tax consequences when using a tax-exempt entity in crowdfunding are addressed by current tax laws, primarily in Code sections 501 through 515 and Code section 170. ${ }^{64}$ The donation, pre-purchase, and reward crowdfunding models are the primary models used for tax-exempt crowdfunding. ${ }^{65}$ In general, contributions received by a tax-exempt organization are not subject to income tax. ${ }^{66}$ For example, those

62. I.R.C. § 707(a); Treas. Reg. §§ 1.707-1, -3, -6.

63. See Creator Questions, KicKSTARTER, https://www.kickstarter.com/help/faq/creator+questions?ref=faq_nav\#GettStar (last visited Sept. 29, 2015) ("If you're not running the project as a nonprofit, but instead working with a 501(c)(3) fiscal sponsor, be sure that your account details (specifically, the 'Account' tab of your project) is set up by the 501(c)(3). You must also include details about the organization on the project page."); see also How to Raise Tax-Deductible Funds, INDIEGoGO, https://support.indiegogo.com/hc/enus/articles/202444736? (last visited Sept. 29, 2015) (explaining how to set up a campaign to raise money for a 501(c)(3) organization).

64. I.R.C. $\S \S 501-15,170(2012)$.

65. But see supra notes 32-37 and accompanying text.

66. I.R.C. $\$ \S 501-05$. 
contributors who provided $\$ 1, \$ 10$, and $\$ 15$ in exchange for a "thank you" from the producers of the Guy-Blaché film gave a total amount of $\$ 7,363 .^{67}$ This donation model of crowdfunding, which involves an entity that has tax-exempt status, would exclude from income taxation the $\$ 7,363$ received by the documentary filmmakers. ${ }^{68}$ In addition, it would provide a charitable-contribution deduction to each contributor up to the amount each provided. ${ }^{69}$

The pre-purchase and reward crowdfunding models have similar tax consequences, but both are different from the donation model. ${ }^{70}$ The sale of goods or services by a tax-exempt entity will not result in income tax to the entity if those activities are engaged in furtherance of its exempt activities. ${ }^{71}$ Income tax may be avoided by an exempt organization even if the activities are not in furtherance of the entity's exempt purpose if those activities are an "insubstantial part" of the exempt organization's activities. $^{72}$ Activities that are not in furtherance of an exempt activity and are more than an "insubstantial part" of the overall activities may be taxed at regular rates if determined to create "unrelated business taxable income." " "Unrelated business taxable income" is defined in Code section 512 as "gross income derived by any organization from any unrelated trade or business ... regularly carried on by it," which is determined by the facts and circumstances of each situation. ${ }^{74}$ The bottom line is that the perks and rewards will not be taxable income to the exempt organization if they are in furtherance of the entity's exempt purpose or are an "insubstantial part" of its overall activity, but the income they generate could become taxable if the facts and circumstances support a conclusion that it is derived from an unrelated trade or business that is regularly carried on. ${ }^{75}$

The act of providing goods and services (perks and rewards) to contributors by a tax-exempt organization utilizing pre-purchase and

67. Green \& van Sluijs, supra note 24 .

68. I.R.C. $\S 501$.

69. Id. § 170 .

70. See infra Part IV.

71. I.R.C. § 501(c)(3).

72. Treas. Reg. § 1.501(c)(3)-1 (2015) (providing an "operational test" that allows for an "insubstantial part" of the exempt organization's activities to not be in furtherance of its exempt purpose).

73. I.R.C. $\$ 511(\mathrm{a})$.

74. See id. $\S 513$ (explaining circumstances of unrelated trade or business); see also Treas. Reg. § 1.513-1 (defining "unrelated business taxable income").

75. The determination of the facts and circumstances that would result in unrelated business taxable income is beyond the scope of this Article. 
reward crowdfunding models also has tax consequences for the contributors. It is clear that contributions made to tax-exempt organizations provide the contributor with a charitable deduction. However, a charitable deduction is not allowed if the contributor receives goods and services in exchange for their contribution unless the payment provided exceeds the fair market value of the goods and services received, and at the time the payment is made the contributor intends to make a payment that exceeds the fair market value of the goods and services received. ${ }^{76}$ The first part of the latter rule is objective, that is, either the amount provided for the goods and services exceeds the fair market value of the goods and services, or it does not. The second inquiry seeks to determine if the donor's intention is to make a contribution or gift at the time that the donation is made. If the two requirements are met, then the amount of the charitable deduction the contributor is allowed to claim is limited to the value of the property provided by the contributor over the amount of the fair market value of the goods and services the contributor receives. ${ }^{77}$ For example, those contributors who provided $\$ 35$ in exchange for a digital download of the film could claim a charitable deduction in the amount of $\$ 15$ if the fair market value of the digital download was $\$ 20$. In essence, there is a "dual payment" in which a single payment results in two different tax results - a result that has been characterized as a "version of the part-gift, part-sale transaction., ${ }^{, 78}$

An interesting issue arises when a tax-exempt crowdfunding organization lends money to third parties without charging interest for the use of the funds, for example, Kiva. Although it is clear that charitable contributions are allowed as a deduction in determining the income taxes of the contributor, ${ }^{79}$ interest-free loans are not allowed as a charitable deduction. ${ }^{80}$ Professor Lawsky explains that interest-free loans donate the time value of money, ${ }^{81}$ which is a donation of a partial

76. Treas. Reg. § 1.170A-1(h); Rev. Rul. 67-246, 1967-2 C.B. 104; United States v. Am. Bar Endowment, 477 U.S. 105, 116-17 (1986).

77. Treas. Reg. $\$ 1.170 \mathrm{~A}-1(\mathrm{~h})$. "The congressional purpose for allowing the donor a deduction is to encourage the infusion of private funds into the public sector. The charitable functions that the donee organizations perform serve a governmental purpose, and many of those functions would have to be undertaken by the government if charities were not there to perform them." Douglas A. Kahn \& Jeffrey H. Kahn, "Gifts, Gafts, and Gefts" - The Income Tax Definition and Treatment of Private and Charitable "Gifts" and a Principled Policy Justification for the Exclusion of Gifts from Income, 78 Notre DAME L. REV. 441, 513-14 (2002).

78. Kahn \& Kahn, supra note 77, at 502.

79. I.R.C. $\$ 170(a)(1)$.

80. Lawsky, supra note 21 , at 1534.

81. Id. at 1535 . 
interest in property that is clearly prohibited as a charitable deduction under the regulations. ${ }^{82}$ Professor Lawsky's article argues convincingly that the law should be reformed so as to allow a charitable deduction for foregone interest on loans in these crowdfunding situations. ${ }^{83}$

\section{TAX CONSEQUENCES OF CROWDFUNDING MODEL 1 (DONATIONS) AND MODELS 2 AND 3 (REWARD \& PRE-PURCHASE)}

\section{A. Income Taxation}

It is well settled that income subject to taxation is determined under Commissioner v. Glenshaw Glass Co. ${ }^{84}$ and Code section $61 .{ }^{85}$ The Supreme Court in Glenshaw Glass provided that income is "undeniable accessions to wealth,... over which the taxpayers have complete dominion." 86 The Code and the Regulations also provide an allencompassing definition which states that "income means all income from whatever source derived," unless it is otherwise excluded by law. ${ }^{87}$ The Code also provides a non-exclusive list of items that are taxable income, which include the following: "[c]ompensation for services . . ; [g]ross income derived from business; [g]ains derived from dealings in property; [and] interest." 88 For example, the contributors to the GuyBlaché film provide income for the producers when, in exchange for money, they "spend the day with the filmmakers in Los Angeles (travel and accommodations are not included) to review the research and behind the scenes action in telling Alice's amazing story." ${ }^{\text {"P }}$ Put simply, the filmmakers are providing their time, knowledge, and experiences in

\footnotetext{
82. Id. at 1527 .

83. Id. at $1546-51$.

84. 348 U.S. 426, 431 (1955). See Alice G. Abreu \& Richard K. Greenstein, Defining Income, 11 Fla. TAX REV. 295, 296 \& n.1 (2011) [hereinafter Defining Income], for a clarification of accepting Glenshaw Glass as defining income. The Glenshaw Glass definition is rooted in the HaigSimons definition of income which states: "Personal income may be defined as the algebraic sum of (1) the market value of rights exercised in consumption and (2) the change in the value of the store of property rights between the beginning and end of the period in question." Theodore P. Seto, When Is a Game Only a Game?: The Taxation of Virtual Worlds, 77 U. CIN. L. REV. 1027, 1040 \& n.58, 1041 (2008) (quoting Henry C. Simons, Personal Income TAXation 50 (1938)). As Professor Theodore P. Seto points out, this is simply "income equals consumption plus change in net worth" and it is "generally only invoked by scholars." Id. at 1040 n.58, 1041.

85. I.R.C. § 61 (2012).

86. Glenshaw Glass, 348 U.S. at 431.

87. I.R.C. § 61(a); Treas. Reg. § 1.61-1(a) (2015).

88. I.R.C. § 61(a). The regulations add that "gross income includes income realized in any form, whether in money, property, or services.” Treas. Reg. § 1.61-1.

89. Supra note 29 and accompanying table.
} 
making the film in exchange for the contributors' money. Because these perks are within crowdfunding they may appear to be simply a nice gesture and not the provision of services in exchange for money. To draw an analogy, if Steven Spielberg received money from the public to be allowed to spend time with him as he explained and reviewed research and behind the scenes action in making one of his films, the receipt of money for his services would clearly be income to Spielberg. Also, those contributors who provided $\$ 35$ in exchange for a digital download of the film provided the producers with gross income that was derived from business. ${ }^{90}$ In addition, when contributors provided $\$ 99$ in exchange for a DVD copy of Alice Guy-Blaché's film, A Fool and His Money, the producers received gains derived from dealings in property. ${ }^{91}$ Therefore, based on the plain language of the law it could be concluded that funds obtained from crowdfunding should be accounted for by the recipients as taxable income. In fact, Kickstarter has provided guidance stating that the money obtained on Kickstarter is income. ${ }^{92}$ But, at the same time, the IRS has declined to clarify its position on the tax treatment of crowdfunding.

Although it is reasonable at this point in the analysis to consider the money received in crowdfunding as income, there are still issues that need exploration. The inclusiveness of the definition of income would suggest that all accessions to wealth, when realized, are income. ${ }^{93}$ However, as Professor Bittker noted, "[w]hen we turn to the field of income taxation ... we do not begin with a consensus on the meaning of income, but with a myriad of arguments about what should be taxed, when, and to whom" " added, "[t]he arguments have not abated in the intervening years-if anything they are now more intense. $" 95$ There are numerous examples of

90. See I.R.C. § 61(a)(2) (defining gross income as including " $[\mathrm{g}]$ ross income derived from business").

91. See I.R.C. § 61(a)(3) (defining gross income as including "[g]ains derived from dealings in property").

92. Kickstarter and Taxes: A Guide for Your Accountant, KICKSTARTER, https://www.kickstarter.com/help/taxes (last visited Sept. 29, 2015).

93. See Bryan T. Camp, The Play's the Thing: A Theory of Taxing Virtual Worlds, 59 Hastings L.J. 1, 29 (2007) ("The realization requirement boils down to timing. Before an accession to wealth is reportable as gross income, it must be realized. This requirement mediates between the economic idea of income and the practical needs of a system dependent on periodic reporting of transactions that may or may not have closed. It has less to do with economic theory and more to do with finding an administrable legal concept of gross income." (footnotes omitted)).

94. Boris I. Bittker, A "Comprehensive Tax Base" as a Goal of Income Tax Reform, 80 HARV. L. REV. 925, 985 (1967).

95. Defining Income, supra note 84, at 340. A reason cited for such disagreements has been the failure of Glenshaw Glass to identify the factors that determine if there is an "accession to 
activities that meet the Glenshaw Glass definition of income that are nevertheless either not immediately taxed or even excluded altogether from taxable income by either the IRS, the courts, or the legislature. Examples in a business context include the personal use of frequent-flier miles obtained from an employer ${ }^{96}$ and other employee fringe benefits. ${ }^{97}$ Examples from personal activity include self-benefitting services, ${ }^{98}$ baseballs caught by spectators at a game, ${ }^{99}$ free samples from businesses, ${ }^{100}$ animals caught by hunters, ${ }^{101}$ and minerals obtained from mining. ${ }^{102}$ Professor Abreu and Professor Greenstein have concluded that "neither the courts, nor tax scholars, nor the IRS have articulated a comprehensive theory that explains all of these specific outcomes."103 However, Professor Abreu and Professor Greenstein provide a workable explanation, concluding that these examples illustrate that the definition of income is better understood as a standard and not a rule. ${ }^{104}$ That is, the income definition in Glenshaw Glass should not be approached as a rule that is solely consistent with economics but as a standard that allows for the consideration of other values in determining whether or not there is taxable income. ${ }^{105}$ The scope of these values can be limited to

wealth." Id. at 339-40.

96. Leandra Lederman, "Stranger than Fiction": Taxing Virtual Worlds, 82 N.Y.U. L. REV. 1620, 1646 n.138 (2007).

97. Internal Revenue Serv., DeP't of the Treasury, Publ'N No. 15-B, Employer's TAX GUIDE TO FRINGE BENEFITS 5-20 (2014), http://www.irs.gov/pub/irs-pdf/p15b.pdf.

98. Camp, supra note 93, at 38; see also Defining Income, supra note 84, at 297 n.9 ("Every major tax casebook and treatise acknowledges that imputed income is not income for tax purposes.").

99. Defining Income, supra note 84, at 344 ("Those tax lawyers [IRS] would probably agree that equity and efficiency point toward taxing the value of the baseball (because it is an accession to wealth clearly realized within the taxpayer's dominion if she keeps it) .... But as lawyers working for the IRS they understand the difficulty of administering such a conclusion, not only because of the difficulty of valuation but also because it necessarily implies taxing all caught baseballs, including those of relatively little value. Such a result, while equitable and efficient, is unadministrable, not only because people would rebel but also because it would be impossible for the IRS to enforce it." (footnotes omitted)).

100. Id. at $317-18$.

101. Camp, supra note 93, at 65 ("Acquisition of virtual items would therefore be like a hunter who takes game, a fisher who takes fish, or a farmer who harvests the crop.").

102. Adam S. Chodorow, Ability to Pay and the Taxation of Virtual Income, 75 TENN. L. Rev. 695, 706 \& n.73 (2008) (citing Treasurey Regulation section 1.61-4 regarding self-grown crops); Lawrence A. Zelenak \& Martin J. McMahon, Jr., Taxing Baseballs and Other Found Property, 84 TAX NOTES 1299, 1302-04 (1999) (discussing commercial fisherman, big game hunters, prospectors and miners, and treasure hunters).

103. Defining Income, supra note 84, at 298.

104. Id. at 339 .

105. Id. at $344-46$. 
traditional tax policy standards such as administrability and equity, ${ }^{106}$ or it can be an all-things-considered inquiry. ${ }^{107}$ In other words, it can also account for other values such as privacy, social cooperation, and improvement of the standard of living. ${ }^{108}$ Regardless of the scope of values applied, it is clear that the consideration of values other than raising revenue from realized accessions to wealth best explains why the latter examples have been determined to fall outside taxable income, even though such transactions clearly meet the strict definition of income. $^{109}$

It is interesting to note that the IRS has yet to provide guidance that specifically states that funds received in crowdfunding campaigns are taxable income. ${ }^{110}$ It could be argued that there are four possibilities that might explain the IRS's lack of definitive guidance on this issue. First, the IRS may have concluded that-similar to self-benefitting services, child support, and baseballs caught by spectators-crowdfunding revenue is not income that the IRS will use its resources to tax. ${ }^{111}$ Second, it may have concluded that, like cash welfare payments, such funds are not taxable income. ${ }^{112}$ Third, it may have concluded that crowdfunding encompasses too many facts and circumstances to make it possible to take a bright-line position, and it will only lead to litigation similar to cases involving free samples from businesses and fringe benefits for employees. ${ }^{113}$ Fourth, it does not currently have a conclusion because it has not yet internally examined all the tax consequences of crowdfunding. The current lack of IRS guidance, lack of case law, and lack of legislative action specifically addressing the income tax issues of crowdfunding requires an exploration of priorities that may outweigh the primary objective of raising revenue. Such an exploration may support a conclusion that crowdfunding is income that should not be taxed even though these funds meet the definition of income under Glenshaw Glass

\footnotetext{
106. Id. at 345 .

107. See Alice G. Abreu \& Richard K. Greenstein, It's Not a Rule: A Better Way to Understand the Definition of Income, 13 Fla. TAX REV. 101, 105, 107 (2012) [hereinafter It's Not a Rule] (discussing varying approaches to defining income, including rejection of a rigid model in favor of an all-things-considered analysis).

108. Id. at 107-09 (discussing and citing Douglas A. Kahn, Exclusion from Income of Compensation for Services and Pooling of Labor Occurring in a Noncommercial Setting, 11 FLA. TAX REV. 683, 687-89 (2011)).

109. Defining Income, supra note 84, at 299-300.

110. See supra notes $10-12$ and accompanying text.

111. See supra notes $98-99$ and accompanying text; see also It's Not a Rule, supra note 107, at

112. It's Not a Rule, supra note 107 , at 103.

113. Defining Income, supra note 84 , at $313,318$.
} 103. 
and Code section 61. Certain assumed values could be viewed as holding greater priority than that of raising revenue from crowdfunding. At this point, it is worth exploring these values.

\section{B. Values that Have Been Determined to Exclude Certain Activities from Taxable Income}

As noted above, a number of activities have been found to meet the definition of income under Glenshaw Glass and Code section 61 but nevertheless have not been taxed. ${ }^{114}$ Before examining crowdfunding, so as to determine if it should be excluded from income taxation, it is necessary to understand the values that have been put forward to support the exclusion from income tax in the case of other activities like those mentioned above. Many of the values supporting tax exclusion in those examples have been administrative and include the following: (1) the lack of ascertainable fair market value of the property subject to tax; (2) the risk of noncompliance by taxpayers; (3) the lack of liquidity to pay taxes owed; (4) the costs associated with reporting such income and enforcing payment; and (5) the small amounts subject to tax resulting in an inefficient allocation of tax enforcement resources. ${ }^{115}$ Other values supporting exclusion include the desire to avoid government intrusion into citizens' privacy and the overall detrimental tax effects from taxing income where deductions are disallowed. ${ }^{116}$ The question is: how do these values apply to crowdfunding? The following section examines crowdfunding models 1,2 , and 3 to determine if they may indicate a determination that funds received through these models could be excluded from income taxation.

\section{The Application of the Above Values to Model 1 (Donation) and Models 2 and 3 (Reward and Pre-Purchase) to Determine Possible Income Tax Exclusion}

Funding campaigns created in Kickstarter, IndieGoGo, and similar crowdfunding sites are rarely only Model 1. For example, if every donation amount in the Guy-Blaché film campaign yielded a reward of a "thank you" then it would not only be a very unusual crowdfunding

114. See supra notes $96-102$ and accompanying text.

115. Chodorow, supra note 102, at 740.

116. Joseph M. Dodge, Accessions to Wealth, Realization of Gross Income, and Dominion and Control: Applying the "Claim of Right Doctrine" to Found Objects, Including Record-Setting Baseballs, 4 Fla. TAX REV. 685, 704, 726 (2000). 
campaign, but also one that has not provided any goods or services in exchange for the funds. Discussed below are more common campaigns that $d o$ contain rewards of goods and/or services provided to the parties supplying the funds for the project. Whether these transactions are a gift for income tax purposes will be discussed in Part V. For purposes of this discussion, the first step is to acknowledge that receipt of funds in Model 1 is income under Glenshaw Glass, Code section 61, and the regulations under Code section $61 .^{117}$ Further, the examples of activities that have been removed from taxable income based on other values-for example, free samples, caught baseballs, etc. ${ }^{118}$ - would not appear to change this conclusion.

An important differentiating factor in the receipt of crowdfunding property compared to other nontaxed property is that the property received in crowdfunding is cash. Cash has an ascertainable fair market value and there is generally no liquidity issue regarding the taxes owed. Further, crowdfunding activities occur through intermediary companies on the Internet, which renders the activity subject to relatively easy reporting and enforcement, and also provides a lower risk of noncompliance by taxpayers, while at the same time reducing enforcement as an issue of the government's intrusion into citizens' privacy. In addition, as reported above, the amounts subject to tax are currently billions of dollars (and rising), ${ }^{119}$ therefore, on a cost/benefit basis, enforcement is an efficient allocation of government resources that is likely to result in relatively large amounts of taxable income.

On the other hand, there is a factor that may support the case for not taxing crowdfunding money in that it may give rise to administrative burdens. Deductions that are related to crowdfunded projects may be disallowed. This may create an overall detrimental effect on taxpayers and economic activity as well as giving rise to a liquidity issue if these funds are taxed. Most crowdfunding sites require the party requesting the funds to clearly state what the funds will be spent on, ${ }^{120}$ and many of the crowdfunding campaigns promise to spend the money on a project or activity that, for tax purposes, may be considered a for-profit business

\footnotetext{
117. See supra notes $84-88$ and accompanying text.

118. See supra notes $96-102$ and accompanying text.

119. See supra notes 6-8 and accompanying text.

120. Examples of crowdfunding sites that require a crowdfunder to clearly state what the funds will be used for include Kickstarter.com, IndieGoGo.com, RocketHub.com, and PledgeMusic.com. See, e.g., Kickstarter Basics: Kickstarter 101, KICKSTARTER, https://www.kickstarter.com/help/faq/kickstarter+basics?ref=footer (last visited Sep. 29, 2015) (requiring projects to state a "clear goal").
} 
endeavor. ${ }^{121}$ The Code contains many limitations that restrict or disallow deductions relating to money spent on for-profit endeavors or in a trade or business as well as restricting or disallowing funds spent on personal, living, or family expenses. ${ }^{122}$ For example, expenditures on films in forprofit endeavors, such as the Guy-Blaché film, are generally capitalized $^{123}$ and deducted as depreciation ${ }^{124}$ using one of the available depreciation methods. ${ }^{125}$ Each of the depreciation methods allows only a percentage of the total expenses to be deducted each year over many future years. ${ }^{126}$ The taxpayer making the film is required to include the full $\$ 200,000$ in gross income in the year the funds are received, but will only be allowed to claim a small amount as a depreciation deduction each year. ${ }^{127}$ If the taxpayer chooses the straight-line method of depreciation, where it is determined that the film has a useful life of twenty years and a salvage value of zero, then the taxpayer can deduct $\$ 10,000$ per year for twenty years. ${ }^{128}$ In the first year, the taxpayer will have $\$ 190,000$ in taxable income yet will have spent all or most of all of the $\$ 200,000$ on creating the project, as legally required through the crowdfunding site, thereby leaving the taxpayer with a sizable amount of tax owed with no funds with which to pay.

This raises a clear "inability to pay" issue for the taxpayer based on the lack of liquidity. One can easily see the possibility of the negative economic result, namely, a reduction in the number of crowdfunding projects because of the income tax liability that would arise. ${ }^{129}$ However,

121. See id. (noting the variety of projects and project purposes allowed on Kickstarter.com).

122. For examples see Code sections 183, activities not engaged in for profit; 67, $2 \%$ floor on miscellaneous itemized deductions, including subparagraph (c)'s application to pass-through entities; 465, at-risk rules; 469, limitations on passive activity losses and credits; and 262, disallowing deductions for personal, living, and family expenses.

123. I.R.C. $\$ 263 \mathrm{~A}(\mathrm{a})(1)(\mathrm{B}),(\mathrm{b})(1)(2012)$.

124. Id. § 167(a) (2012). Taxpayers' ability to deduct film and television production expenses in the year incurred rather than over a number of future years under Code section 167 expired as of December 31, 2013. Id. $§ 181$ (Supp. 2014). Film and television productions are not eligible to use the Modified Accelerated Cost Recovery System ("MACRS") under Code section 168(f)(3) or amortization under Code section 197.

125. The straight-line and income-forecast methods are applicable to motion pictures. $I d$. $\S$ 167(a), (g).

126. Id. § 167(g) (income-forecast method); Treas. Reg. § 1.167(b)-1(a) ("Under the straight line method the cost or other basis of the property less its estimated salvage value is deductible in equal annual amounts over the period of the estimated useful life of the property.").

127. See supra notes 87-91 and accompanying text.

128. Treas. Reg. $\S 1.167$ (b)-1(a). The numbers chosen in the example are for brevity and clarity and do not necessarily reflect the best method of depreciation allowance.

129. See Daniel Shaviro, A Case Study for Tax Reformers: The Taxation of Employee Awards and Other Business Gifts, 4 VA. TAX REV. 241, 246 (1985) (noting that, in the context of taxing employee benefits, "it can be argued that taxing employee awards is inefficient, in that it would 
these administrative challenges would not necessarily remove crowdfunding receipts from taxable income because the funds received are cash which gives taxpayers the opportunity to budget for the payment of income tax by segregating the funds for taxes from the total funds received in the crowdfunding campaign. The taxpayer would simply be required to include the taxes to be owed in the budget that the taxpayer creates when planning the overall crowdfunding endeavor. ${ }^{130}$

The tax consequences of for-profit endeavors (above) is substantially similar to endeavors that are not engaged in for profit (so called "hobby losses"), that is, receipt of taxable income but the inability to deduct costs incurred in spending such taxable income. ${ }^{131}$ Although different Code sections will apply to restrict or disallow the deductions, the conclusion remains the same: a taxpayer in an endeavor not engaged in for profit should simply be required to include the taxes to be owed in the original budget of the crowdfunding endeavor.

Crowdfunding models with rewards, including where the reward is a pre-purchase of the item to be produced in the crowdfunding campaign, provide goods and/or services to the parties providing the funds. These transactions are determined under Code sections 61 and 1001, and it is clear that these transactions are taxable income. ${ }^{132}$ For example, in the Guy-Blaché film campaign funds received in the amount of \$35 in exchange for a pre-purchase of the final film are transactions covered under Code section 61 and section 1001. ${ }^{133}$ An example of services in the campaign would be the reward provided in exchange for a $\$ 5,000$ contribution as identified in the chart above, namely, "spend the day with the filmmakers in Los Angeles (travel and accommodations are not included) to review the research and behind the scenes action in telling Alice's amazing story." 134 None of the values that have previously supported an exclusion of otherwise taxable income ${ }^{135}$ apply to these

destroy the economic value of a particular form of behavior").

130. See Chodorow, supra note 102, at 739 (providing examples of items federal tax laws have included in income although there is a clear inability-to-pay/liquidity issue).

131. If Code section 183 is applicable, then the taxpayer may only deduct expenses related to the activity to the extent of income from that activity. I.R.C. $\S 183(a)-(b)$. Code section 67 (2\% floor on miscellaneous itemized deductions) and Code section 68 (overall limit on itemized deductions) limit an individual taxpayer's ability to claim itemized deductions.

132. See I.R.C. $\S 61$; see also Treas. Reg. §§ $1.61-2$ to $-3,-6$.

133. See I.R.C. $\S 1001$ (b) ("The amount realized from the sale or other disposition of property shall be the sum of any money received ....").

134. See supra note 29 and accompanying table; Treas. Reg. § 1.61-2(d) ("If the services are rendered at a stipulated price, such price will be presumed to be the fair market value of the compensation received in the absence of evidence to the contrary.").

135. See supra notes $114-16$ and accompanying text. 
crowdfunding transactions. However, there are two issues that are raised when services are exchanged for the crowdfunded money: first, assigning value to each reward provided in each funding amount; and second, determining the value of the services provided. The taxpayer is required to value each good and service (reward) that is provided within each funding category in order to allocate costs to each item in determining deductions. $^{136}$ Code section 61 and the regulations clearly state that funds received for services are valued at the amount received. ${ }^{137}$ The full amount received in exchange for more than one reward is taxable income. And, one may easily conclude that the allocation of the fairmarket-value of the total amount of each of the rewards provided by the taxpayer-project is an issue relevant to deducting expenses in regard to each reward. This is not an impossible task for the taxpayer to complete and would not, therefore, justify removing these rewards from taxable income. This is different than the conclusions reached regarding frequent-flier miles and self-benefitting services where it has been determined to be too difficult to assign an accurate fair market value to each item for income tax purposes. ${ }^{138}$

\section{Gift Tax Laws Applicable to Model 1 (Donation), Model 2 (REWARD), AND MODEL 3 (PRE-PURCHASE)}

\section{A. Introduction and Assumptions}

"Gross income means all income from whatever source derived, unless excluded by law." ${ }^{39}$ As discussed in Part IV above, the funds received in crowdfunding campaigns are taxable gross income. One example of a transfer that is excluded from gross income by law is the value of property acquired by gift, bequest, devise, or inheritance. ${ }^{140}$ Therefore, crowdfunding receipts are taxable unless they can be excluded as a gift under Code section 102. However, before discussing the law that assesses whether or not crowdfunding receipts may be excluded

136. See U.S. TAx Court, Rules of Practice ANd Procedure, Rule 142(a), at 96 (2012), https://www.ustaxcourt.gov/notice.htm ("The burden of proof shall be upon the petitioner ....") (to navigate URL, scroll down until find Title XIV, click blue hyperlink); see also I.R.C. § 7491 (2012) (listing exceptions to the burden of proof rule).

137. I.R.C. § 61; Treas. Reg. §§ 1.61-1 to -3, -6; see also Treas. Reg. § 1.61-2(d) (addressing compensation paid other than in cash and stating that, "[i]f the services are rendered at a stipulated price, such price will be presumed to be the fair market value of the compensation received in the absence of evidence to the contrary").

138. Camp, supra note 93, at 27-28.

139. Treas. Reg. $§ 1.61-1(a)$.

140. I.R.C. § 102(a) (2012). 
from income as a gift, there are several issues to be addressed. First, the Code and supporting regulations identify a few specific types of payments as ineligible for exclusion as a gift, but it should be noted that they provide little guidance regarding the types of payments that are considered a gift. ${ }^{141}$ Second, since its inclusion in the Revenue Act of 1913, legislators have not provided policy reasons supporting the gift exclusion. ${ }^{142}$ Such legislative policy guidance could be invaluable in the application of the law to new areas such as crowdfunding. ${ }^{143}$ Third, it is the IRS's position regarding the determination of gifts for income tax purposes that it will not issue letter rulings or determination letters advising taxpayers whether a transfer is a gift within the meaning of Code section 102(a). ${ }^{144}$ Fourth, scholars have debated whether or not gifts should be excluded from income at all, and some have argued that there is no principled rationale for supporting the exclusion of these receipts from taxable income. ${ }^{145}$ It must be determined if proper reasoning supporting the gift exclusion exists, and if so, whether that reasoning assists in evaluating the exclusion of crowdfunding receipts specifically. An assumption underlying this Article is that there is proper foundation for the gift tax exclusion from income based on the policy that "the payment of an income tax purchases the right to have the taxed income used by the taxpayer, or by someone else of the taxpayer's choosing, to acquire and consume societal goods or services."

141. Kahn \& Kahn, supra note 77 , at 445 . For example, income from gift-property is not also a gift excluded from income. I.R.C. $§ 102(b)$. Code section 102 does not apply to "prizes and awards," "scholarships," or "fellowship grants." Treas. Reg. § 1.102-1(a).

142. Richard Schmalbeck, Gifts and the Income Tax-An Enduring Puzzle, 73 LAW \& CONTEMP. PROBS. 63, 77 (2010).

143. See William A. Klein, An Enigma in the Federal Income Tax: The Meaning of the Word "Gift", 48 MinN. L. REV. 215, 238-46 (1963) (providing a brief survey of the origin and development of the income tax, the estate tax, and the gift tax from 1816 to 1954); see also Debra Lefler, Comment, "Keeping Books on Romance": The Gift Exclusion in Nonmarital Relationships, 105 Nw. U. L. REV. 1739, 1744 n.31 (2011) (listing sources that discuss the gift exclusion).

144. Rev. Proc. 2014-3, 2014-1 I.R.B. 111 (2014) ("There are ... certain areas in which, because of the inherently factual nature of the problems involved, or for other reasons, the Service will not issue rulings or determination letters.").

145. For scholars who argue that there is a principled rationale to support exclusion of gifts from taxable income see Douglas A. Kahn, The Taxation of a Gift or Inheritance from an Employer, 64 TAX LAW 273, 274 n.6 (2010); Kahn \& Kahn, supra note 77, at 441; see also Schmalbeck, supra note 142, at 63-65. For scholars arguing that no policy justification exists to support exclusion of gifts from taxable income see Henry C. Simons, Personal Income TAXation 56-58 (1938); Joseph M. Dodge, Beyond Estate and Gift Tax Reform: Including Gifts and Bequests in Income, 91 HARV. L. REV. 1177, 1182-89 (1978); Klein, supra note 143, at 215, 260-63; Marjorie E. Kornhauser, The Constitutional Meaning of Income and the Income Taxation of Gifts, 25 ConN. L. REV. 1, 28-37 (1992); Lawrence Zelenak, The Reasons for a Consumption Tax and the Tax Treatment of Gifts and Bequests, 51 TAX L. REV. 601, 602-03 (1996).

146. Kahn \& Kahn, supra note 77, at 444; Kahn, supra note 145, at 278 ("Consumption requires 
Assuming the latter is a valid assumption, it is next necessary to examine the current law to determine when the gift exclusion would apply to crowdfunded income. It should be noted that the types of payments that qualify for the gift income-tax exclusion has been left to the courts to determine. ${ }^{147}$ Commissioner v. Duberstein has become the standard for determining whether a transfer is a gift for income tax purposes. $^{148}$ The Supreme Court provided several guidelines in Duberstein, which include the following: (1) a gift is determined on a case-by-case basis and is basically an issue of fact; ${ }^{149}$ (2) a gift is not determined based on the donor's characterization of the payment, but must be based on an objective inquiry; ${ }^{150}$ (3) whether or not a gift has occurred is based on consideration of all of the factors; ${ }^{151}$ and (4) the determination of a gift must be based on "the application of the factfinding tribunal's experience with the mainsprings of human conduct to the totality of the facts of each case." Duberstein is that a gift does not proceed "primarily from ... 'any moral or legal duty' or from 'the incentive of anticipated benefit' of an economic nature," 153 but from a "detached and disinterested generosity," 154 and "out of affection, respect, admiration, charity or like impulses." 155 Put simply, "the most critical consideration... is the transferor's 'intention."

Professor Abreu and Professor Greenstein reached the conclusion that the definition of "income" is best understood as a standard and not a rule, ${ }^{157}$ and they also suggest that the determination of transfers that qualify for gift exclusion from income is a standard and not a rule. ${ }^{158}$ They expressed it with the following language:

\footnotetext{
the destruction or preclusive use of property or services.").

147. See, e.g., Comm'r v. Duberstein, 363 U.S. 278, 285-86 (1960) (discussing whether certain payments fit under the Court's definition of a gift); see also I.R.C. $\$ 102$ (a) (stating merely that a gift is excluded from income without giving any definition).

148. Kahn \& Kahn, supra note 77, at 445-46.

149. Duberstein, 363 U.S. at 290.

150. Id. at 286 (" $[\mathrm{W}]$ hat the basic reason for his conduct was in fact- the dominant reason that explains his action in making the transfer.").

151. Id. at 288 .

152. Id. at 289 .

153. Id. at 285 (quoting Bogardus v. Comm'r, 302 U.S. 34, 41 (1937)).

154. Id. (quoting Comm'r v. LoBue, 351 U.S. 243, 246 (1956)).

155. Id. (quoting Robertson v. United States, 343 U.S. 711, 714 (1952)).

156. Id. (quoting Bogardus, 302 U.S. at 43). "What controls is the intention with which payment, however voluntary, has been made." Bogardus, 302 U.S. at 45 (Brandeis, J., dissenting).

157. Defining Income, supra note 84 , at 339 .

158. It's Not a Rule, supra note 107, at 112-13.
} 
[A] nuanced, multifaceted analysis might be precisely what the Duberstein Court intended when it referred to the "nontechnical nature of the statutory standard," and what led it to reject the Government's request to adopt a single-factor, rule-like test under which gifts would "be defined as transfers of property made for personal as distinguished from business reasons." 15

The assumption in this Article is that the language of the Duberstein Court is clear on its face and requires a gift analysis to be a standard requiring a nuanced, multifaceted analysis. The Court's requirement that a determination is based on "consideration of all the factors" and "the totality of the facts in each case" clearly means that every fact is to be weighed before reaching a conclusion. Of course, different factors are given more weight in different situations, and reasonable people can differ regarding which factors are the most important in any given situation.

This Article will adopt two further assumptions regarding the application of the gift income tax exclusion as applied to crowdfunding receipts. The first assumption is that the determination of whether a transfer is a gift or income should take into account the balance between the transferor's right to expend previously taxed funds as he or she desires on the one hand and the basic premise that income to a recipient is taxable for the support of the government on the other. ${ }^{160}$ That is, this balance must be one of the factors in the "totality of factors" considered in making a gift or income determination. The second assumption is that the requirement that a transferor's intent is "detached and disinterested" is not met only if the "primary motive of the donor is selfish." "161 This assumption is supported by the Duberstein Court's explanation that the goal of the inquiries is to determine "the basic reason for [the transferor's] conduct ... the dominant reason that explains his action in making the transfer." 162

\footnotetext{
159. Id. at 114 (footnote omitted).

160. See Kahn \& Kahn, supra note 77, at 467-68.

161. See id. at 478-79. Professor Douglas A. Kahn and Professor Jeffrey H. Kahn explain that a transferor cannot be held to a standard of having no selfish motives, otherwise very few transfers would occur. Id. Further, they point out that "[t]he psychological make-up of human beings is complex. There often are mixed motives for making voluntary transfers." Id. at 478.

162. Comm'r v. Duberstein, 363 U.S. 278, 286 (1960).
} 


\section{B. Crowdfunding and the Gift Tax Implications}

\section{Crowdfunding Factors Affecting the Determination of a Gift}

As stated above, Duberstein requires consideration of all factors in gift determinations. ${ }^{163}$ The problem is that when it comes to crowdfunding, there are no applicable reported cases and there is no IRS guidance regarding the gift-tax exclusion. Even though there is a lack of guidance regarding crowdfunding specifically, there are cases that provide guidance of a general nature that could be applied to gift determinations in the case of crowdfunding. The following discussion will examine the two broadly applicable determinant categories in the establishment of a gift exclusion that are present in crowdfunding. These two categories can be viewed as primary factors in the determination of the gift exclusion in regard to crowdfunding campaigns.

The first category is whether the party providing money receives any tangible goods or services in exchange for the funds. The second category is the circumstances surrounding the transfer of funds, including whether the recipient accepts the funds in the capacity of an individual or a business. The Duberstein Court clearly states that the transferor's intent in making a transfer must be determined in order to be able to make a gift determination. As cited above, the Court also stated that a gift is not determined by the donor's own characterization of the payment, but must be based on an objective inquiry. ${ }^{164}$ It is an assumption of this Article that although a transferor's personal reasons for providing funds are certain to be varied, ${ }^{165}$ those personal reasons are not solely determinative. As an illustration, each crowdfunding donor could be required to provide a signed statement that their payment is intended as a "gift"; nevertheless, such statements would not determine whether or not a "gift" had occurred. An analysis would have to be based solely on the objective facts of the situation, which will be the guiding principle of the following analysis.

163. See supra notes $148-56$ and accompanying text.

164. Duberstein, 363 U.S. at 286.

165. Mollick, supra note 30, at 3 (stating that in crowdfunding the "actual goals of funders are extremely heterogeneous," such as "to support a cause..., to personally support the project founders, as a political statement, as a joke, or for any one of a number of other reasons." (footnote omitted)). 


\section{Tangible Goods or Services}

One of the factors in determining if a transfer is indeed a gift is whether or not the party making the gift receives something tangible in return. Depending on the structure of the campaign, a party providing crowdfunding money (the funder) may or may not receive tangible goods or services from the crowdfunding recipient. Not receiving tangible goods or services in exchange for the funds would strongly indicate a gift. ${ }^{166}$ From an objective point of view, the dominant reason the party is providing the funds would not be because of a moral duty or a perceived economic benefit but rather because of generosity. ${ }^{167}$ It is when a funder receives tangible goods or services in exchange for money that the issue of whether or not a gift can be claimed arises. Receiving goods or services in exchange for funds, as an isolated factor, is not an objective indication that a transaction is a gift. ${ }^{168}$ However, since it is required that a gift determination must be made based on the totality of the factors involved and because the Duberstein Court also states that the basic or dominant reason which explains the transferor's intent in making the transfer must be determined, it is still possible that a gift can occur in a crowdfunding context even if the funder received goods or services in return for the funds. ${ }^{169}$ For example, an additional factor of significant relevance in making an objective determination of a transferor's intent is the fair market value of the goods and services provided from the crowdfunding campaign to the funder, particularly in relationship to the total amount of funds provided by the funder. To illustrate, the 605 funders who each provided $\$ 35$ to the Guy-Blaché film in exchange for a digital download of the film would most likely not be able to prove that the exchange was a gift because objectively it could be concluded that a pre-purchase of the film was the basic or dominant reason for giving $\$ 35$. The logic behind the latter is that the fair market value of a digital copy of a feature-length documentary is between $\$ 10$ and $\$ 50$. On the other hand, if a funder provided $\$ 10,000$ in exchange for the digital copy of the documentary then it would be clear that the dominant reason for the transaction was generosity and not obligation or a perceived benefit, thus the transaction could be a gift. In spite of the exchange of a good for cash, the gift determination would be predicated on the disproportionate

166. This type of crowdfunding is the donor model.

167. See supra notes 151-62 and accompanying text.

168. Duberstein, 363 U.S. at 285-88; see Note, Tax Consequences of Transfers of Bodily Parts, 73 Colum. L. REV. 842, 844-45 (1973).

169. See infra notes 192-201 and accompanying text. 
ratio between the $\$ 10,000$ funding and the $\$ 10$ to $\$ 50$ estimated value of the digital copy. These, of course, are extremely clear-cut examples, whereas in reality the facts are much less cut and dry. Exactly how the fair market value of the items provided from the crowdfunding campaign to the funders should impact the gift determination in crowdfunding will be addressed below in Part VI.

\section{Impact of Individual vs. Business Status on Gift Determination}

Based on the plain language of Duberstein, it could be argued that whether the party accepting the funds is an individual or a business should not be determinative of whether the funds received are a gift. That is, the circumstances surrounding the transferee's acceptance of the funds should not be determinative of whether there is a gift transfer because the language of Duberstein focuses on the transferor's intent. ${ }^{170}$ However, the clear language of Duberstein also states that the gift determination is based on "consideration of all the factors" and "the totality of the facts of each case."171 Whether the transferee is an individual or business is definitely a circumstance involved in the transfer that should make it a relevant fact. Rulings by the courts ${ }^{172}$ and examination of the issue by tax scholars ${ }^{173}$ further support the conclusion that the circumstances surrounding the actions of the transferee do influence the determination of a gift and must be considered. ${ }^{174}$ There

\footnotetext{
170. Duberstein, 363 U.S. at $285-86$.

171. Id. at $288-89$.

172. See infra Part V.B.3.a.

173. See Kahn \& Kahn, supra note 77, at 481-82 ("The Ninth Circuit is not alone in believing that Duberstein established the transferor's intent as the exclusive test for gift treatment. But the Supreme Court's decision was made in a factual context in which no competing principles were invoked that might have led the Court to modify that test. In a subsequent case presenting facts that do invoke a competing principle, a court could decide whether that competing principle carries sufficient weight to justify a modification of the Duberstein rule. The better approach would be to recognize that there are circumstances where the role or actions of the transferee will prevent a transfer from qualifying as a gift, even though the transferor holds the requisite intention for a gift. This approach recognizes that the decision to exclude gifts rests on a balancing of competing principles, and the actions of a transferee in certain circumstances will enhance the weight to be accorded to what otherwise would be the subordinated principle." (footnote omitted) (emphasis added)).

174. Professor Douglas A. Kahn and Professor Jeffrey H. Kahn examine these issues and conclude that "the Duberstein rule should be revisited by the Supreme Court and modified to recognize that there are circumstances where it is proper for the action of the transferee to control the characterization of the transaction." Id. at 483 (emphasis added). I agree with their conclusions, but I take the position that the Duberstein rule may only need to be clarified because the Court ruling expressly requires all facts and factors be considered in determining a gift. Subsequent rulings have
} also interpreted the Duberstein rules in this manner when weighing the transferee's actions. 
are no reported cases or guidance from the IRS regarding the determination of income as opposed to a gift in the crowdfunding context, but the following provides a synopsis of cases and IRS guidance provided in non-crowdfunding circumstances, the basic principles of which may be applicable to crowdfunding.

\section{a. Individuals Receiving Funds}

Olk v. United States ${ }^{175}$ is an example where the court considered the circumstances of the transferee in its evaluation of a gift transaction regardless of the intent of the transferor. ${ }^{176}$ Dealers working at casinos sometimes received "tokes" (betting chips representing money) from customers. ${ }^{177}$ The court noted that the dealers did not perform specific services in exchange for the tokes, other than doing their jobs for their employers, and the dealers combined the tokes and split them evenly at the end of the night. ${ }^{178}$ The court noted that the patrons were under no obligation to provide the tokes, and approximately $90-95 \%$ of the patrons gave nothing to the dealers. ${ }^{179}$ The court also noted that customers gave the tokes to the dealers "as a result of impulsive generosity or superstition." ${ }^{\text {180 }}$ Professor Douglas A. Kahn and Professor Jeffrey H. Kahn highlight the language in Olk to support their conclusion that the court strongly considered the nature of the circumstances regarding the transferees in finding that the tokes were taxable income in reversal of the district court's gift determination. ${ }^{181}$ They quote the following from $O l k$ :

Moreover, in applying the statute to the findings of fact, we are not permitted to ignore those findings which strongly suggest that tokes in the hands of the ultimate recipients are viewed as a receipt indistinguishable, except for erroneously anticipated tax differences, from wages. The regularity of the flow, the equal division of the

\footnotetext{
175. 536 F.2d 876 (9th Cir. 1976).

176. Id. at 877-79. The trial court ruled that "[t]he tokes are given to dealers as a result of impulsive generosity or superstition on the part of players, and not as a form of compensation for services." Id. at 877 . The appellate court accepted the latter as the dominant reason the transferors provided the tokes, but the appellate court then stated that "in applying the statute to the findings of fact, we are not permitted to ignore those findings which strongly suggest that tokes in the hands of the ultimate recipients are viewed as a receipt indistinguishable, except for erroneously anticipated tax differences, from wages." Id. at 879.

177. Id. at 877 .

178. Id.

179. Id.

180. Id.

181. Kahn \& Kahn, supra note 77 , at 481 .
} 
receipts, and the daily amount received indicated that a dealer acting reasonably would come to regard such receipts as a form of compensation for his services. The manner in which a dealer may regard tokes is, of course, not the touchstone for determining whether the receipt is excludable from gross income. It is, however, a reasonable and relevant inference well-grounded in the findings of facts. ${ }^{182}$

Professors Kahn and Kahn also provide further examples that support the conclusion that the circumstances surrounding an individual's acceptance of money can be facts supporting a determination that funds received are taxable income even when the transferor has the clear intent to make a gift. ${ }^{183}$ The first example they give is as follows:

$\mathrm{X}$ fraudulently disguises himself to appear seriously handicapped and impoverished. Using that disguise, and sitting on a busy corner of a large city, X induces passersby to "give" him money, the total of which comes to a large sum. The people who gave X the money did so out of sympathy for his plight and out of detached and disinterested generosity. Nevertheless, the donations made to $\mathrm{X}$ are income to him. He obtained the donative intent of the transferors through fraudulent action, and he should not be allowed to obtain a tax benefit thereby. ${ }^{184}$

Another example given is a professional beggar who makes no false representations and obtains a substantial amount of donations on the street from people who have the required donative intent. ${ }^{185}$ They explain that the situation is similar to an adult child receiving a monthly allowance from his or her parents, which generally does not result in taxable income. ${ }^{186}$ Noting that the professional beggar's receipts could reasonably be determined to be either income or a gift, their conclusion is that these funds are income. ${ }^{187}$ They reason that the "balancing of the two competing principles (the principle of maximizing the choice of consumption for the donor and the principle of accurately measuring each individual's ability to pay)" supports their conclusion since the accurate measurement of income is given greater significance based on the facts in their example. ${ }^{188}$ It is reasonable to conclude from the

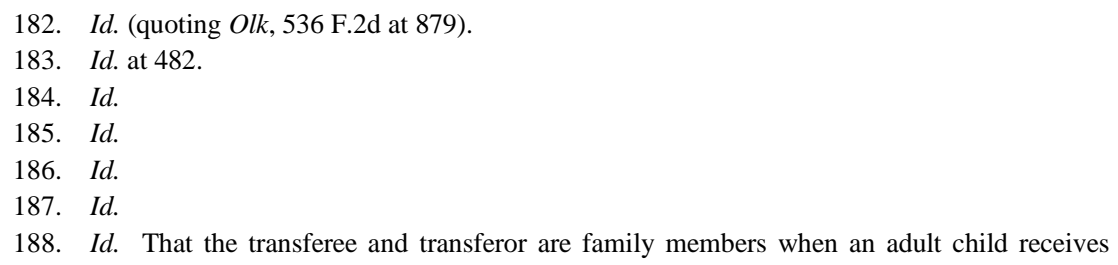


Professors' professional beggar example that the frequency and regularity of the receipt of money in the manner described is a factor that will generally indicate income rather than a gift when applied to other transferor-transferee situations. Of course, additional factors could come into play, like the relationship of the givers to the receivers. For example, family members often have a relationship with the receiver of funds that supports a finding of intent based upon affection. Whereas receiving funds from strangers in crowdfunding most likely would not support a finding that the giving is based on affection. However, it should be noted that receipts from strangers can be based on "respect, admiration, charity, or like impulses." 189 That is, the isolated fact that strangers provide funds should not preclude a finding that a transaction is a gift. ${ }^{190}$

Kralstein v. Commissioner ${ }^{191}$ provides an example of facts that are somewhat similar to those involved in crowdfunding. Mr. Kralstein was a vice president of the Bakery and Confectionery Workers' International Union of America. ${ }^{192}$ The unions sponsored a testimonial dinner for him and they actively solicited donations for the cost of the dinner and the cost of creating and distributing a souvenir journal. ${ }^{193}$ Any funds remaining after paying the costs were to be given to Mr. Kralstein for personal items and to purchase a home. ${ }^{194}$ Mr. Kralstein did not plan or arrange the solicitations, journal, or dinner. ${ }^{195}$ Further facts include: (1) each dinner was $\$ 25$ a head; (2) the cost of placing an ad and greetings for Mr. Kralstein in the journal was between $\$ 50$ and $\$ 750$ for each ad; (3) a total of $\$ 85,470$ was raised, consisting of $\$ 33,825$ for the dinner and $\$ 51,645$ for the journal; (4) approximately 750 people involved in the baking industry were solicited, approximately 400 provided funds for the journal, and between 1,300 and 1,400 people attended the dinner; (5) the cost of having the dinner was approximately $\$ 18,000$, the cost of printing the journal was approximately \$6,250, and Mr. and Mrs. Kralstein

regular funds from his or her parents is a fact that also supports the gift determination; a fact that is altered when an individual solicits funds from the general public with whom the transferee does not have such a family relationship. See id.

189. Comm'r v. Duberstein, 363 U.S. 278, 285 (1960) (quoting Robertson v. United States, 343 U.S. 711,714 (1952)).

190. See Dietz, supra note 10, at 303 ("While gifts often occur between friends and family, exchanges between business partners, an employer and employee, and even complete strangers can be considered gifts as well.").

191. 38 T.C. 810 (1962).

192. Id. at 811 .

193. Id. at 812 .

194. Id. at $812,814-15$.

195. Id. at 812 . 
personally received approximately $\$ 61,000$ to purchase a home and for personal items. ${ }^{196}$

Several conclusions drawn by the court are instructive for evaluating the tax consequences involved in crowdfunding. The court reviewed the standards provided in Duberstein and determined that $\$ 12,000$ of the $\$ 61,000$ that Mr. and Mrs. Kralstein received was a nontaxable gift. ${ }^{197}$ This is an important determination for crowdfunding because the court noted that the people who provided funds received a dinner in exchange for the funds, ${ }^{198}$ and, although it was not specifically stated, it is a reasonable presumption that those parties that provided money for the journal also received a copy of the journal. Therefore, Kralstein is an example of a donor providing funds, receiving tangible goods in return, and the transaction being considered a gift based on the "totality of factors" standard required by Duberstein.

Another important determination from the court came when it rejected the claim that the union was the actual donor of the funds. The court stated that it was "plain that not merely one purported gift is here in question, but literally hundreds of purported gifts" made by "persons with varying interests." "199 By analogy, crowdfunding amounts are not received from any intermediary such as Kickstarter but are traced to each individual donor. Further, although the court found that the greater part of the funds provided were not gifts because those parties provided them with the belief that they would obtain some business benefit, the court took into account all of the factors in its decision because Duberstein requires the gift determination to be "reached on consideration of all the factors. $" 200$ The determination of gift or income in crowdfunding also requires consideration of all of the facts. Among those relevant factors in Kralstein were that these parties made their contribution by business check, took a business deduction for the contributions, and that testimony was presented that these parties believed the payments were expected for business reasons. ${ }^{201}$

b. Collecting Funds in the Course of a Business

Another factor influencing a gift determination in a crowdfunding

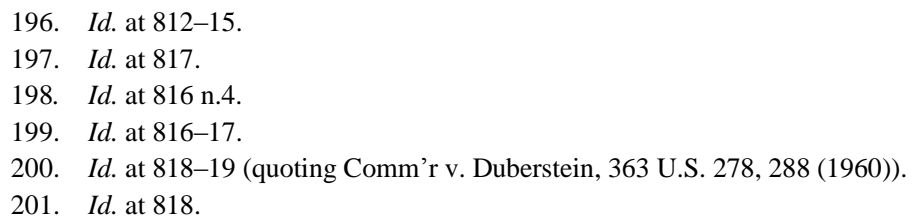


campaign is whether or not the transferee soliciting and accepting the funds is a business. Case law and guidance from the IRS shed light on the issues regarding on-going trades and businesses that have solicited and collected funds from the general public, and it is a factor that affects the gift determination in the crowdfunding context.

In Publishers New Press, Inc. v. Commissioner, ${ }^{202}$ the Tax Court ruled that funds solicited from customers were provided in consideration of the "normal business function" of Publishers New Press's business of publishing a newspaper, and the receipt of such funds was therefore income and not a gift. ${ }^{203}$ Publishers New Press was a New York corporation that published a daily and weekly newspaper. ${ }^{204}$ Over three years the company made public appeals through its publications cautioning readers that if contributions were not immediately forwarded to the company it would go out of business. ${ }^{205}$ The court noted that the publisher was a corporation organized and operating in pursuit of profit and that the only way the company could continue to provide its service was by asking for amounts more than it charged for sales of its newspapers. ${ }^{206}$ Further, if the company dissolved at any time then its assets above its debts could be distributed to its shareholders. ${ }^{207}$ The court's examination of the contributors' intent in these circumstances resulted in its conclusion that the primary intent of the contributors was to obtain something that they desired, that is, they sent the funds in order to continue to receive the service of the publication of the newspaper which the court stated were payments "made in consideration of the performance of the petitioner's normal business function of publishing a newspaper," which is income and not a gift. ${ }^{208}$

206. Id. at 398-400. The court cited Teleservice Co. of Wyoming Valley v. Commissioner, 27 T.C. 722 , aff'd, 254 F.2d 105 (3d Cir. 1958), as "somewhat analogous" to the Publishers New Press, Inc. case. Id. at 400. Although Teleservice was decided before Duberstein, the facts were similar to Publishers New Press because prospective customers were solicited by Teleservice Company to finance a community television system. Id. The court found that such payments were income because "the only way that the (corporation) could be induced to give service was by receipt of something in addition to the monthly charge, namely, contributions to enable it to construct extensions of the antenna system." Id. (quoting Teleservice Co., 27 T.C. at 730).

207. Id. at 398-99.

208. Id. at 401. The court also cited Webber v. Commissioner, 21 T.C. 742 (1954), aff'd, 219 F.2d 834 (10th Cir. 1955), as a similar situation to Publishers New Press, Inc. Id. at 400-01. In that case, which was decided before Duberstein, a minister conducted a radio show for profit and solicited contributions from listeners. $I d$. at 400 . The court found that, because the minister made a
} 
In Revenue Ruling 73-356 209 and in General Counsel Memorandum $36,796^{210}$ the IRS has further addressed solicitations of contributions in the conduct of a trade or business. In Revenue Ruling 73-356, the IRS addressed the situation where a congressman offers a newsletter to constituents at a reasonable subscription price, supplementing any deficiency in amounts received out of his own funds. ${ }^{211}$ The IRS found the subscription fees to be income to the congressman and not a gift because the funds were provided as a direct payment for the newsletters. ${ }^{212}$ A second congressman sends reports to his constituents twelve to fifteen times a year; he also solicits contributions from them to defray the costs but sends the newsletter to all constituents whether or not they provide a contribution. ${ }^{213}$ The IRS also found these solicited amounts to be income and not gifts, arguing that

[t]he performance of the official duties of a Congressman in his trade or business as an elected official includes keeping his constituents informed .... Thus, any amount received by a Congressman for the purpose of defraying part of the cost of reporting to constituents ... is a substantial benefit to him in that it offsets a portion of the cost to him of performing the duties of his office. ${ }^{214}$

The IRS clearly, and correctly, determined that the first congressman engaged in a sales transaction - that is, payment for a service. Citing Publishers New Press, the IRS determined that the second congressman was in a similar position as the taxpayer in that case. ${ }^{215}$ The IRS focused on the congressman, determining that although the contributions were not payments for the publications, he still received a substantial benefit from his constituents for apparently doing his job-keeping constituents informed. ${ }^{216}$ However, not addressed by the IRS is the fact that - unlike customers who are listening to a radio program that they do not want to stop or receiving a newspaper that they enjoy reading and do not want it to go out of business - constituents are not required to provide funds to

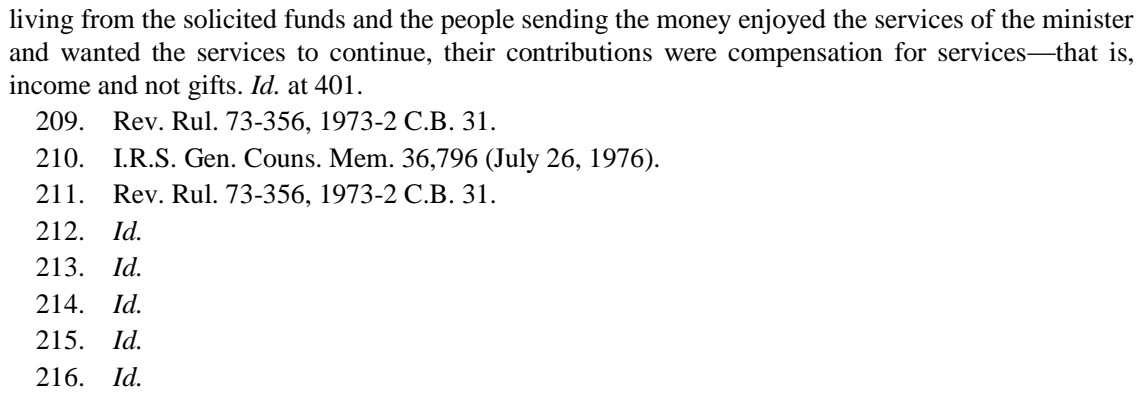


continue to receive information from their representatives. As the IRS stated, keeping constituents informed is a duty of being a representative. Therefore, the IRS's reliance on Publishers New Press. is misplaced because the "primary intent" of transferors/customers who are receiving goods and services that will discontinue without further payments is distinctly different from the intent of transferors who either do not have a vendor/customer relationship with the transferee or who are not motivated by the potential discontinuance of a good or service that they wish to continue receiving.

Further, although the IRS cited Duberstein in its ruling, its reasoning supporting its conclusion that the second congressman did not receive gifts does not indicate that it weighed "the totality of factors" that is required to find the "primary intent" of the transferor when evaluating whether a transaction is a gift. ${ }^{217}$ In fact, in its determination that there was no gift, the IRS seemed to rely on a conclusion that the congressman received a substantial benefit when he received amounts that assisted him in the duties that are within his job description, without discussing the primary intent of the transferors or the totality of factors. ${ }^{218}$ The IRS's omission of an analysis of these factors undercuts its conclusion that such funds are income.

Although it is true that general counsel memoranda are not to be relied upon or otherwise cited as precedent by taxpayers, ${ }^{219}$ they do provide an understanding of the reasoning underlying the IRS's approach to an issue. General Counsel Memoranda 36,796 (GCM 36,796), issued three years after Revenue Ruling 73-356, brings out two additional points. First, determining whether a transaction is a gift requires personal judgments upon which reasonable individuals can disagree; and second, whether a gift occurs can change based on the facts of each and every transaction. ${ }^{220}$ So, a proper determination requires the IRS to expend resources and time to review all facts in every transaction in order to determine whether the transaction is included as income or is excluded as a gift. In GCM 36,796, the IRS again reviewed the tax consequences of funds received by a congressman to pay for publication and dissemination of voter information-facts similar to those in Revenue Ruling 73-396. However, GCM 36,796 contains some facts that are different from the facts of Revenue Ruling 73-396, including the

\footnotetext{
217. Id.; Comm'r v. Duberstein, 363 U.S. 278, 285-88 (1960).

218. Rev. Rul. 73-356, 1973-2 C.B. 31.

219. I.R.S. Gen. Couns. Mem. 36,796 (July 26, 1976).

220. Id.
} 
following: (1) an oral trust was created to obtain memberships from the general public in exchange for $\$ 100$ per year; (2) anyone could contribute regardless of residence or political affiliation; and (3) the congressman did not control the funds, had no authority to pay any bills, and could not compel the trust to make payments on his behalf. ${ }^{221}$ The IRS did not find that the differences in facts changed the conclusion it reached in Revenue Ruling 73-356 - that is, the IRS determined that the funds received were income and not a gift. ${ }^{222}$ It is interesting to note that the IRS in GCM 36,796 stated that, based on Duberstein and Publishers New Press, it held in Revenue Ruling 73-396 that "since the contributions were made to assure the continued publication of the materials, the amounts received were not gifts. $" 223$ Therefore, it is clear that according to the IRS and the courts, payments made by a payor to a business in order to assure the continuation of a service from that business are income to the business and not a gift. One could make the case, however, that a one-time payment, unrelated to the continuation of a good or service from the recipient, is distinguishable from the payments at issue in Revenue Ruling 73-396 and GCM 36,796. Therefore, such a payment, without regard to the other factors present in the transaction, would not necessarily be considered income because the primary intent of the transferor is not the continuation of a good or service.

\section{How Existing Gift Laws Apply to Crowdfunding Model 1}

(Donations) and Models 2 and 3 (Reward and Pre-Purchase)

Although the gift determination is based on the facts and circumstances of each situation, ${ }^{224}$ one may draw broad conclusions from the law, as well as guidance from the patterns of thinking presented above. ${ }^{225}$ First, it is clear that since there is not just one but multiple gifts from an intermediary (for example Kickstarter) to the crowdfundee used in a crowdfunding campaign, it is necessary to examine the facts and circumstances of each individual transaction between the crowdfundee and each funder in order to make an income or gift determination. ${ }^{226}$

To put the implications of these facts into some perspective, just one

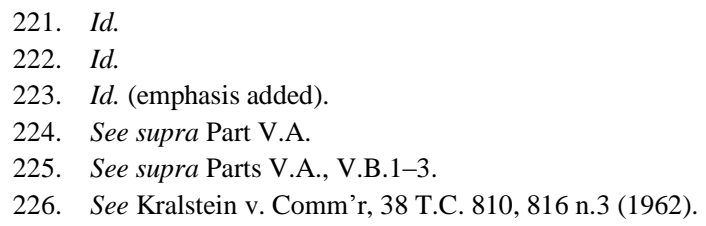


crowdfunding intermediary, Kickstarter, reported that between 2009 and 2015, 9 million backers made more than 24 million total pledges, receiving a plethora of goods and services in the process. ${ }^{227}$ First, these statistics mean that taxpayers and the IRS will be required to expend the time and resources necessary to examine each factor in every transaction to try to comply. ${ }^{228}$ Second, if the provider of the funds receives no tangible good or service in return for the funds, it would be a strong indicator that the transferor's intent supports a classification of the transaction as a gift. ${ }^{229}$ Third, even if a funder does receive tangible goods or services in return, it may still be possible for such transactions to be a gift - at least to the extent that the fair market value of the goods and services received is less than the funds provided by the transferor. ${ }^{230}$ In fact, the more the amount provided by the transferor is greater than the fair market value of the goods and services received, the greater the possibility that the transaction can be classified as a gift. ${ }^{231}$

Fourth, certain facts about the transferee in a transaction can significantly alter a gift determination, ${ }^{232}$ for example, whether the transferee is an individual or a business. ${ }^{233}$ If the transferee is an individual the following factors are important: (1) whether or not the recipient is an employee receiving the funds at work; (2) the frequency and regularity of the receipt of funds; and (3) the relationship of the transferee to the transferor. ${ }^{234}$ An income determination is more strongly indicated if an individual receives funds as an employee, receives them frequently and regularly, and is a stranger to the transferor (since family relationships are more indicative of a gift). ${ }^{235}$ It should be noted that if the recipient is a business, funds that are provided by a customer who

\footnotetext{
227. See supra note 6 and accompanying text.

228. See supra Part V.A.

229. But see supra Part V.B.3.a-b where other factors besides the "intent of the transferor" have been sufficient to find a determination of income and not a gift.

230. Kralstein, 38 T.C. at 818 .

231. The Supreme Court has stated

$[\Pi] f$ the payment proceeds primarily from . . . "the incentive of anticipated benefit" of an economic nature, it is not a gift.... A gift in the statutory sense, on the other hand, proceeds from a "detached and disinterested generosity," "out of affection, respect, admiration, charity or like impulses."

Comm'r v. Duberstein, 363 U.S. 278, 285 (1960) (citations omitted).

232. See, e.g., Publishers New Press, Inc. v. Comm'r, 42 T.C. 396, 400 (1964) (finding that funds received to keep publication from failing were not gifts); Olk v. United States, 536 F.2d 876, 879 (9th Cir. 1976) (looking to transferee's perspective when making a gift determination); supra note 182 and accompanying text.

233. See supra Part V.A.3.

234. See supra Part V.A.3.a.

235. Id.
} 
desires the continuation of the business's normal primary function are likely income because the customer's intent strongly indicates that the payments are income. ${ }^{236}$

5. Why Government Action Is Required to Clarify the Application of the Gift Income Tax Exclusion to Crowdfunding

As a revolutionary funding mechanism made possible by new technology, crowdfunding has created challenges to the current laws that define a gift for income tax purposes and will require clarification of the current tax laws. $^{237}$ Since the determination of a gift is based on all of the facts and is to be examined on a case-by-case basis, ${ }^{238}$ the first challenge is to address that aspect of the law which requires taxpayers engaging in a successful crowdfunding campaign to review all of the facts of every transfer of funds in the campaign and make a gift determination accordingly. The second challenge stems from the fact that the IRS is required to either accept the taxpayer's determination without its own review, or review for itself (and at its expense) the facts underlying every gift determination by the taxpayer - fact by fact for each and every transfer. ${ }^{239}$ For example, the successful Kickstarter campaign for the Guy-Blaché film had 3,840 backers that provided approximately $\$ 219,000 .^{240}$ The taxpayer receiving those funds would have $\$ 219,000$ in taxable income ${ }^{241}$ unless the funds can be designated as a gift; however, in order to exclude the amounts received as a "gift" all of the factors in each and every one of the 3,840 transactions would have to be evaluated to determine which of the transactions indeed

236. Publishers New Press, Inc., 42 T.C. at 401.

237. See Wendy Gerzog Shaller, The New Fringe Benefit Legislation: A Codification of Historical Inequities, 34 CATH. U. L. REV. 425, 429 (1985) ("Much of the blame for the inequity and theoretical innovation [regarding fringe benefits] belongs to the Service. Historically, it has provided little consistency in its approach to in-kind compensation."); see also Kelcy S. Mullins, Fringe Benefits: IRS Issues Final Regulations, 68 TAXES 259, 259 (1990), http://www.floridaprobatecounsel.com/wp-content/uploads/docs/Corporate/Fringe-Benefits-IrsIssues-Final-Regulations.pdf ("The tax treatment of fringe benefits is an issue that directly affects most employers and employees. Traditionally, employers have provided employees with tax-free fringe benefits in addition to their taxable wages. Unfortunately, there was considerable uncertainty regarding the taxation of employee fringe benefits. Except for a few statutory provisions, the determination of whether noncash benefits created taxable income was left to the courts to be decided on a case-by-case basis. Their interpretations of the scope of the general inclusion rule of Internal Revenue Code Section 61 varied.").

238. Comm'r v. Duberstein, 363 U.S. 278, 288 (1960).

239. See id. at 287-88; see also Kralstein v. Comm'r, 38 T.C. 810, 819 (1962).

240. Green \& van Sluijs, supra note 24.

241. See supra Part IV. 
qualify as an excludable gift. ${ }^{242}$ How many transactions have occurred in all crowdfunding campaigns in the United States is unknown. Also unknown is how many of those transactions would be eligible for exclusion as a gift under Code section 102. To gain an inkling of the magnitude of the challenge, Kickstarter reported that 9,313,328 total funders have made $24,812,229$ pledges for a total of $\$ 1,906,431,990$ provided to crowdfunding campaigns since Kickstarter began in $2009 .^{243}$

The burden of proving a gift is on the taxpayer claiming the income tax exclusion, as is the cost in money and time expended. ${ }^{244}$ However, it must be kept in mind that the basis of sound tax policy is the proper balance of "equity, efficiency, and administrability,"245 and as Professor Abreu and Professor Greenstein adroitly point out:

$[\mathrm{H}]$ aving an administrable tax law is what makes it possible for the system to raise the revenue which is its raison d'etre. An unadministrable system will almost certainly be inequitable and inefficient because it will affect taxpayers arbitrarily, resulting in inequity and inefficiency. Simplicity enhances administrability and administrability is necessary so that the system can raise revenue in an equitable and efficient way. 246

Further, this challenge doesn't solely affect taxpayers. As noted above, this challenge affects the IRS as well as taxpayers. The IRS will be required to either accept taxpayers' gift determinations or expend its limited resources reviewing a huge number of items in a large number of returns that are claiming a gift exclusion for receipts derived from crowdfunding campaigns so that it can determine which returns to audit. ${ }^{247}$ Given the limited resources of the IRS, this would represent a daunting challenge. On top of this, court challenges by taxpayers to IRS determinations would further deplete the limited government resources, and, perhaps more importantly, raise the possibility of conflicting rulings by courts. ${ }^{248}$ In fact, the Duberstein Court addressed the possibility that its decision requiring that all facts be examined on a case-by-case basis could create uncertainty or become unadministrable when it stated: "If

\footnotetext{
242. See supra Part V.B.4.

243. See supra notes 6-7.

244. See sources cited supra note 136.

245. Defining Income, supra note 84, at 305; see also Lederman, supra note 96, at 1658.

246. Defining Income, supra note 84, at 335.

247. See Alm \& Soled, supra note 14, at 445 ("“W]ith its limited budget, the IRS must choose whom to audit, based at least in part on predicted revenue yields.").

248. See supra note 238.
} 
there is fear of undue uncertainty ... Congress may make more precise its treatment of the matter by singling out certain factors and making them determinative of the matters, as it has done in one field of the 'gift' exclusion's former application, that of prizes and awards." 249 Clearly, the gift determination in crowdfunding campaigns is just such a situation wherein taxpayers and the IRS are required to make factual determinations regarding millions of transactions, ${ }^{250}$ many of which fall into areas that do not lend themselves to obvious and clear resolutions. ${ }^{251}$

\section{WHAT CAN BE RECOMMENDED TO ADDRESS THE CHALLENGES?}

It is recommended that the IRS issue guidance stating clearly that funds acquired in crowdfunding campaigns are taxable gross income required to be reported as such on appropriate tax forms. It is further recommended that the IRS provide a safe harbor allowing taxpayers who complete crowdfunding campaign Models 1, 2, and 3 (Donation, Reward, and Pre-Purchase) to claim a gift for transactions that contain certain facts. The following is a list of the facts that would affect a gift determination: (1) the contributor to the crowdfunding campaign receives nothing in return for the funds contributed, or the amount contributed to the campaign is at least ten times greater than the fair market value of all goods and/or services received from the recipient of the funds; (2) the funds are received by an individual and not a business; (3) the funds are not provided by a current or future customer; (4) the funds are given by a relative, acquaintance, or friend; (5) the crowdfundee receives funds from two or less crowdfunding campaigns in a calendar year; (6) the crowdfundee is contractually required to spend all funds on a specific endeavor and receives no income from the funds; and (7) the crowdfundee is not receiving funds in the capacity of employee.

The IRS should advise taxpayers that there is a rebuttable presumption that the transaction is a gift if it has the first two factors (numbers 1 and 2) in addition to three of the five remaining factors (numbers 3 through 7). The IRS should also require taxpayers to file a statement with the tax return claiming exclusion of crowdfunding receipts from income because such funds are a gift. Such a statement should require taxpayers to identify which factors support the conclusion

\footnotetext{
249. Comm'r v. Duberstein, 363 U.S. 278, 290 (1960).

250. See supra text accompanying note 244 .

251. See supra Part V.B.1-4. See also Alm \& Soled, supra note 14, at 442 (discussing tax treatment of automobile expenses and stating: "Aside from such deliberate violations, the lack of clear rules is another contributory factor in taxpayer noncompliance.”).
} 
that the proper determination for each crowdfunding transaction should be a gift.

A rebuttable presumption will act as a "carrot" to motivate taxpayers to review the facts of each transaction in deciding if a gift determination is appropriate. The rebuttable presumption standard would not preclude the IRS from examining all of the facts of any specific transaction and making its own gift determination, but it would serve to reduce expenditure of IRS resources that would be required to review every transaction. These recommendations would go a long way in achieving a better balance between equity, efficiency, and administrability in the taxing of crowdfunding. 